\title{
Myocardial Phospholipid Remodeling under Different Types of Load Imposed during Early Postnatal Development
}

\author{
F. NOVÁK ${ }^{1,2,5}$, F. KOLÁR $\check{R}^{4,5}$, B. HAMPLOVÁ ${ }^{1}$, L. MRNKA ${ }^{1}$, V. PELOUCH ${ }^{3,5}$, \\ B. OŠŤÁDAL ${ }^{4,5}$, O. NOVÁKOVÁ ${ }^{1}$
}

${ }^{1}$ Department of Cell Biology and ${ }^{2}$ Department of Biochemistry, Faculty of Science, ${ }^{3}$ Second Faculty of Medicine, Charles University in Prague, ${ }^{4}$ Institute of Physiology, Academy of Sciences of the Czech Republic, Prague, ${ }^{5}$ Center for Cardiovascular Research, Prague, Czech Republic

Received October 10, 2009

Accepted October 30, 2009

\begin{abstract}
Summary
Normal increase in hemodynamic load during early postnatal life is associated with heart growth and maturation of membrane structures that is accompanied by remodeling of membrane protein and lipid components. This review describes remodeling of phospholipids $(\mathrm{PL})$ in rat myocardium during normal postnatal development and during accelerated cardiac growth induced by additional workload (aorta constriction, chronic hypoxia and hyperthyroidism) imposed on the heart early after birth. Normal physiological load after birth stimulates the development of membrane structures and synthesis of PL. While hyperthyroidism accelerates these processes, pressure overload has an inhibitory effect. These changes primarily influence the maturation of mitochondrial membranes as cardiolipin is one of the most affected PL species. The most sensitive part of PL structure in their remodeling process are $\mathrm{PL}$ acyl chains, particularly polyunsaturated fatty acids that are the key components determining the basic physicochemical properties of the membrane bilayer and thus the function of membrane-bound proteins and membrane-derived signaling lipid molecules. It is evident that PL remodeling may significantly influence both normal and pathological postnatal development of myocardium.
\end{abstract}

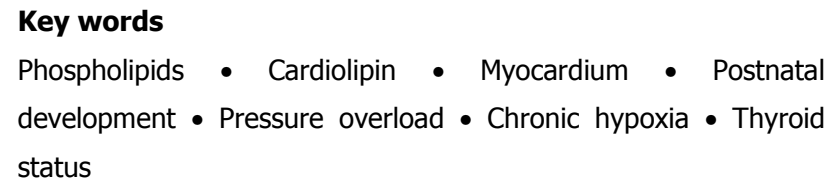

\section{Corresponding author}

Olga Nováková, Charles University, Faculty of Science, Dept. of
Cell Biology, Viničná 7, 12800 Prague 2, Czech Republic. Fax: +420 221951761. E-mail: olnov@natur.cuni.cz

\section{Introduction}

Transition from prenatal to postnatal life is associated with profound changes in the circulation followed by restructuring of the cardiovascular system. The newborn heart possesses high capability to cope with an increased load accompanied by neural and endocrine maturation leading to myocardial growth. This high adaptive potential of the myocardium attenuates during maturation (Oštádal et al. 1999). Just after birth, the heart has to overcome the rapid switch-over from the right ventricle dominance in the fetus to the left ventricle dominance reflected by different growth pattern of both ventricles (Smolich 1995). In most mammals, ventricular myocytes lose their capability of division shortly after birth, and further growth of the heart is solely due to their hypertrophy and hyperplasia/hypertrophy of other cell types (Clubb and Bishop 1984). It was shown that the switch from hyperplastic to hypertrophic growth of rat ventricular myocytes occurs as early as after the third postnatal day (Li et al. 1996). Additional excessive load imposed during the early postnatal period leads to accelerated heart growth response by both myocyte hyperplasia and hypertrophy (Sedmera et al. 2003) accompanied by metabolic changes and remodeling of membranes including proteins (Wibo et al. 1995, Zheng

PHYSIOLOGICAL RESEARCH • ISSN 0862-8408 (print) • ISSN 1802-9973 (online)

(c) 2009 Institute of Physiology v.v.i., Academy of Sciences of the Czech Republic, Prague, Czech Republic

Fax +420 241062 164, e-mail: physres@biomed.cas.cz, www.biomed.cas.cz/physiolres 
et al. 1996) and lipids (Mrnka et al. 1996, Hamplová et al. 2003, Novák et al. 2004).

The principal components of the membrane lipid bilayer are phospholipids (PL) and their ontogenetic remodeling contributes to the modification of membranebound proteins that influence proper heart maturation. Furthermore, membrane PL are precursors of second messengers involved in a variety of signaling pathways. Hence, changes in the quantity and quality of cardiac PL have an indirect effect on the regulation of cardiac function and growth during postnatal development (Tappia 2007).

The present review summarizes the results dealing with remodeling processes of membrane PL and their fatty acid (FA) composition in rat myocardium during normal postnatal development and during accelerated cardiac growth induced by additional workload (aorta constriction, chronic hypoxia and hyperthyroidism) imposed on the heart early after birth.

\section{Phospholipid de novo synthesis and remodeling}

Cellular membranes contain several classes of phospholipids that have numerous structural and functional roles in cells. Heart tissue maintains a distinct content and composition of various PL, such as phosphatidic acid (PA), phosphatidylcholine (PC), phosphatidylethanolamine (PE), phosphatidylglycerol (PG), diphosphatidylglycerol (cardiolipin, CL), phosphatidylinositol (PI), phosphatidylserine (PS) and sphingomyelin (SM) (Nováková et al. 1994). Glycerophospholipids are first formed by the de novo pathway using acyl-CoA as an acyl donor (Kennedy and Weiss 1956). Subsequently, in the remodeling pathway, cycles of deacylation and reacylation of glycerophospholipids modify the FA composition to generate mature membrane PL with asymmetry and diversity (Lands 1958). Polyunsaturated FA (PUFA) are usually located at the $s n-2$ position while saturated FA (SFA) and monounsaturated FA (MUFA) at the $s n-1$ position of glycerophospholipids in an asymmetric manner (Wood and Harlow 1969, Yamashita et al. 1997). Biosynthetic pathways of most glycerophospholipids are localized at the endoplasmic reticulum while $\mathrm{CL}$ biosynthesis takes place in mitochondria. The precursor for glycerophospholipid de novo synthesis is glycerol-3phosphate (G3P) that is acylated in the first step by acylCoA:glycerol-3-phosphate acyltransferase (GPAT)
(Kennedy and Weiss 1956) (Fig. 1A). The resulting lysophosphatidic acid (LPA) is further acylated to PA by acyl-CoA:monoacylglycerol-3-phosphate acyltransferase (LPAAT). PA is converted either to cytidinediphosphatediacylglycerol (CDP-DAG) by CDP-DAG synthase or to DAG by the PA phosphatase. CDP-DAG can be further incorporated into PS, PI, PG and CL while DAG is transferred to CDP-choline or CDP-ethanolamine resulting in $\mathrm{PC}$ and $\mathrm{PE}$ (Fig. 1A). It is necessary to mention that both acyltransferases, involved in de novo PL synthesis in the heart, possess broad substrate affinity for different SFA and MUFA (Zaror-Behrens and Kako 1976) that does not correspond to characteristic acyl chain composition of mature PL in specific cellular membranes with preference for PUFA in $s n-2$ position of individual PL. Thus, the acyl chain remodeling pathways have been proposed to account for the characteristic profile of acyl chains in phosphoglyceride species. Lands' cycle involves a two-step deacylation-reacylation process whereby non-specific acyl chains are cleaved from appropriate $\mathrm{PL}$ by phospholipase $\mathrm{A}_{2} \quad\left(\mathrm{PLA}_{2}\right)$ and generated lyso-PL is reacylated by lyso-PL acyl-CoA acyltransferases with high specificity for unsaturated FA (Fig. 1B) (Lands 1958). Another pathway, participating in PL remodeling, is the transacylation reaction (Yamashita et al. 1997), which involves transfer of acyl chain from various diacyl-PL to lyso-PL (Fig. 1C).

\section{Normal postnatal development of myocardial phospholipids}

\section{Phospholipid species}

The mass of cardiac membrane structures rises dramatically during early postnatal development; the biosynthesis of protein and PL components predominates over its degradation, whereas both processes are more in a dynamic equilibrium in the adult heart under physiological conditions (Girard et al. 1992, Nováková et al. 1994). The time course of changes in the myocardial concentration of total PL is generally proportional to ventricular growth. Nevertheless, there are two exceptions (Fig. 2). In the rat heart, the increment of total PL between postnatal days $\mathrm{d} 2-\mathrm{d} 5$ and $\mathrm{d} 20-\mathrm{d} 40$ is higher than that of ventricular weight (Novák et al. 2006). These periods are considered to be the most critical and stressful periods of rat postnatal life (Olivetti et al. 1980). The first one is characterized by an abrupt increase of cardiac workload and concomitant transition from predominantly anaerobic fetal metabolism of carbohydrates to aerobic 


\section{A. De novo Synthesis}

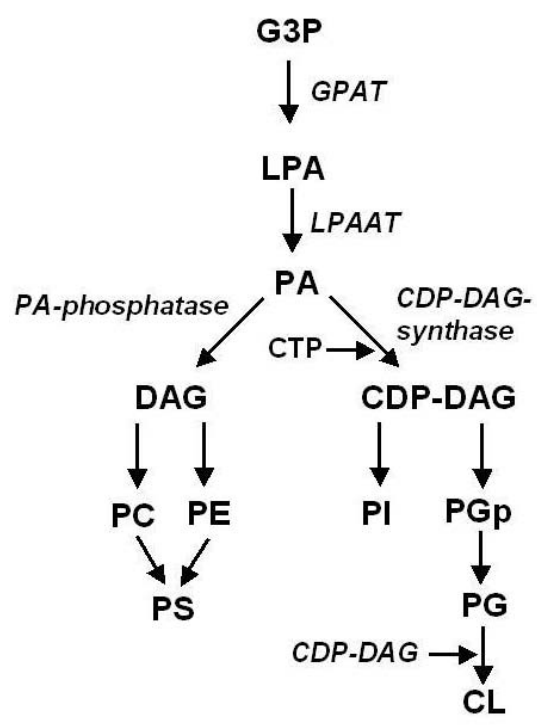

B. Deacylation-reacylation Cycle

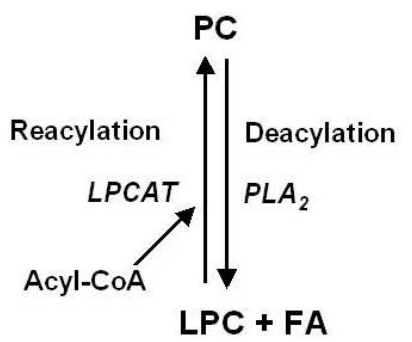

C. Transacylation

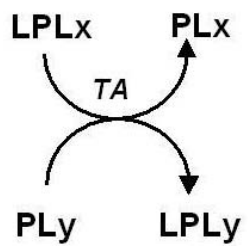

Fig. 1. Simplified scheme of phospholipid de novo synthesis and remodeling pathways. A. G3P (glycerol-3-phosphate), GPAT (acylCoA:glycerol-3-phosphate acyltransferase), LPA (lysophosphatidic acid), LPAAT (acyl-CoA:monoacylglycerol-3-phosphate acyltransferase), PA (phosphatidic acid), CTP (cytidinetriphosphate), CDP-DAG (cytidinediphosphate-diacylglycerol), DAG (diacylglycerol), PC (phosphatidylcholine), PE (phosphatidylethanolamine), PI (phosphatidylinositol), PGp (phosphatidylglycerol phosphate), PS (phosphatidylserine), PG (phosphatidylglycerol), CL (cardiolipin, diphosphatidylglycerol). B. PC (phosphatidylcholine), LPCAT (lysophosphatidylcholine acyltransferase), PLA 2 (phospholipase $A_{2}$ ), LPC (lysophosphatidylcholine), FA (fatty acid). C. LPLX (lysophospholipid x), PLx (phospholipid x), PLy (phospholipid y), LPLy (lysophospholipid y), TA (Acyl-CoA independent transacylase).

metabolism of FA. The second period includes nutritional transition from suckling of mother's milk to solid food intake and initiation of circadian rhythms (Babický et al. 1973, Smolich 1995).

Analysis of individual PL species demonstrates that mainly $\mathrm{PC}$ and $\mathrm{PE}$ are responsible for this uneven rise of total PL concentration during early postnatal development, since these two major PL account for almost $80 \%$ of total PL in the rat heart (Novák et al. 2006). Other studies (Gudmundsdottir and Gudbjarnason 1983, Kumar and Chaudhuri 1993) also reported an increase in the amount of PC and PE in the developing rat heart but, due to different developmental stages analyzed, they did not observe these critical periods. PE is thought to play a crucial role during cardiomyocyte proliferation; there is evidence that this amino-PL plays a pivotal role in the cytokinetic process (Emoto and Umeda 2000). PE resides in the inner leaflet of the majority of eukaryotic plasma membranes (Zachowski 1993) including rat cardiomyocytes (Post et al. 1988). It is probably localized in PE-rich domains (Emoto and Umeda 2000) that tend to form a non-bilayer hexagonal structure, which has been shown to regulate various membrane-bound enzymes, such as phospholipase D (Nakamura et al. 1996) and protein kinase C (PKC) (Bazzi et al. 1992). On the other hand, $\mathrm{PC}$ is more disposed to maintain the lamellar organization of membranes due to its large polar head group, which provides lateral pressure equilibrium between the headgroup and acyl chain level (Goni and Alonso 1999). Besides, PC plays an important role in PKC signaling (Lamers et al. 1992, Slater et al. 1996).

PC and PE occur not only as diacylglycerophospholipids but their $s n-1$ vinyl-etherlinked analogues, plasmalogens, are present in relatively high amounts in the rat myocardium as well (Novák et al. 2006, Post et al. 1988). Plasmalogens are less polar than their ester analogues because of the absence of the ester carbonyl dipole. This fact results in the changes of molecular conformation and consequently in different physicochemical properties of the lipid bilayer (Han and Gross 1990). Plasmalogen content in cardiac membranes differs among mammalian species. For example, the amount of choline plasmalogen (PLPC) is high in human, rabbit, dog and guinea pig myocardium (up to $20-40 \%$ of PC), whereas in rat, mouse and hamster it comprises only 3-8 \% of PC (van der Vusse et al. 1992). Ethanolamine plasmalogen (PLPE) concentration is approximately 5-fold higher than that of PLPC in the rat heart (Hack and Helmy 1988, Novák et al. 2006). In the course of postnatal development, the PLPC proportion drops transiently to a minimum by $\mathrm{d} 5$, grows again by $\mathrm{d} 10$, and then does not change till adulthood (Fig. 3). PLPE 
A.

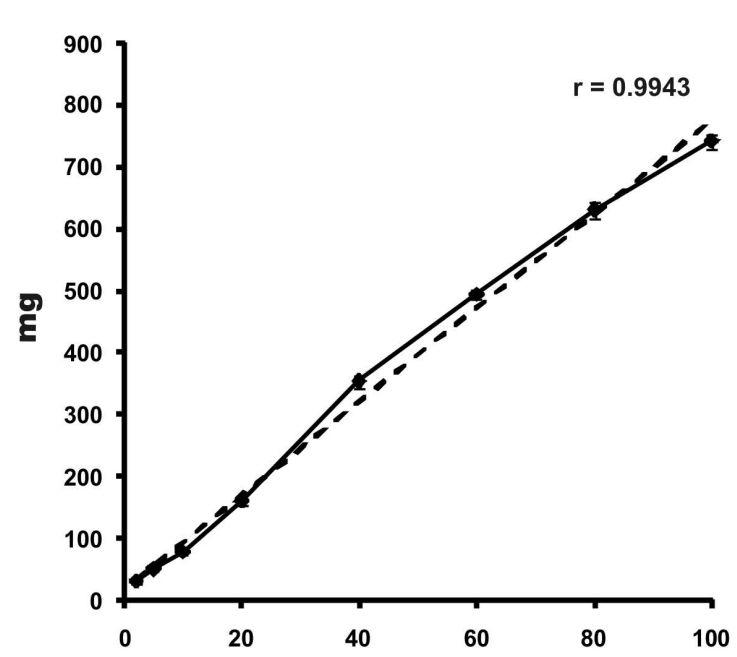

B.

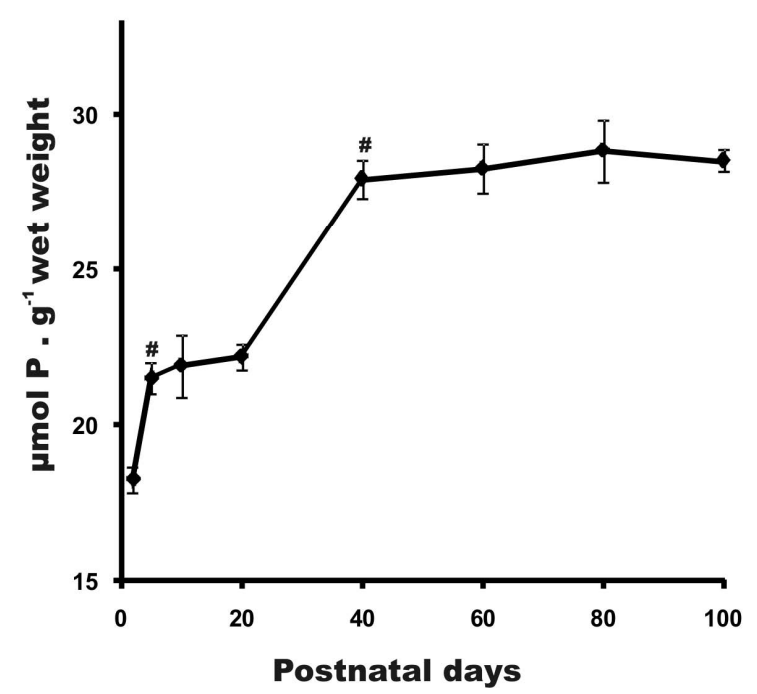

Fig. 2. A. Weights of rat left ventricle (mg wet weight). B. Concentration of total phospholipids in rat left ventricle on postnatal days $2,5,10,20,40,60,80$ and 100 . Values are means \pm S.E.M. from 5 experiments in each group. $\# p<0.05$, significant difference vs. previous stage (adapted from Novák et al. 2006).

proportion falls within the suckling-to-weaning transition (Novák et al. 2006). The dramatic changes in cardiac PLPC and PLPE proportion during early rat ontogeny might be related to the postnatal changes in intracellular $\mathrm{Ca}^{2+}$ transients that also take place in the first postnatal weeks (Escobar et al. 2004). This view is supported by a preferential distribution of plasmalogens in the inner leaflet of the sarcolemma (Gross 1984, Post et al. 1988) and the sarcoplasmic reticulum and by their propensity for inverted hexagonal phase formation (Glaser and Gross 1994), which are indications of their participation in ion transport (Chen and Gross 1994). In line with this, Ford and Hale (1996) showed that plasmalogens provide a critical lipid environment for the regulation of the trans-

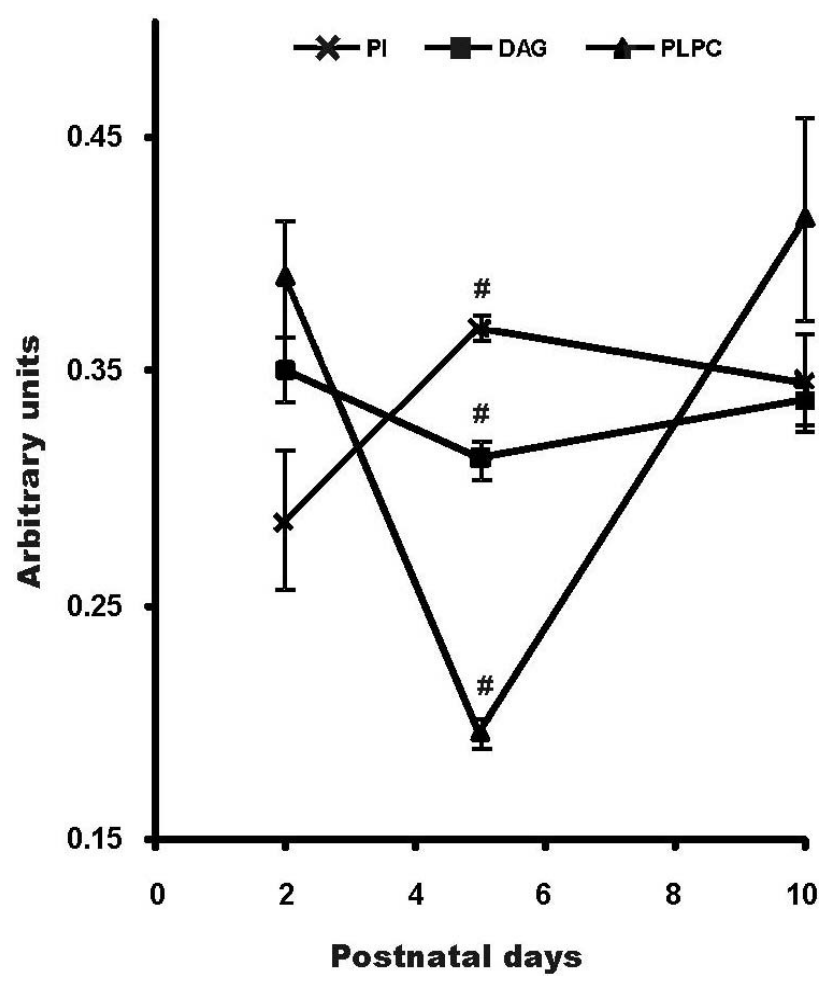

Fig. 3. Developmental changes in the concentration of PI (phosphatidylinositol), DAG (diacylglycerol) and PLPC (choline plasmalogen). Values are expressed as arbitrary units (sum of concentrations measured on postnatal days 2, 5 and 10 is equal to 1$)$. Values are means \pm S.E.M. from 5 experiments in each group. $\# p<0.05$, significant difference vs. 2 -day-old rats (adapted from Novák et al. 2006).

sarcolemmal sodium-calcium exchanger. Plasmalogens also play an important role as a source of second messengers: ether-linked diglycerides as effective activators of PKC (Ford and Gross 1990), and arachidonic acid (20:4n-6) (Glaser and Gross 1994), the precursor of eicosanoids and a potent signaling molecule (Lokuta et al. 1994).

The concentration of CL, a marker of the inner mitochondrial membrane, increases markedly by $\mathrm{d} 40$ (Novák et al. 2006). This almost 3 -fold increase suggests that mitochondrial membranes are predominant structures accounting for the growth of total PL concentration during the first five weeks of rat postnatal life. It has been shown that the interval between $\mathrm{d} 1$ and $\mathrm{d} 4$ is associated with the rapid and large accumulation of mitochondria and myofibrils in rabbit left ventricular (LV) myocardium. Mitochondria are packed more densely with cristae and the area of the mitochondrial inner membrane per unit of myofibrillar volume increases progressively throughout the perinatal period (Smith and Page 1977). In adult rat heart, the area of the mitochondrial inner membrane per unit cell volume exceeds that of the 
sarcoplasmic reticulum by 16 -fold and that of the sarcolemma by about 41-fold in LV myocytes (Page 1978). The rapid increase in CL amount in the neonatal rat heart has been confirmed by incorporation studies using radioactive precursors. The rate of CL biosynthesis is 4.5-fold higher in mitochondria isolated from neonatal rat hearts than in those from adults (Stuhne-Sekalec et al. 1990). CL is known to be associated with several inner mitochondrial membrane proteins (Hoch 1992), the best characterized being its interaction with cytochrome $c$ oxidase. Paradies et al. (1997) demonstrated the close linkage between the content of CL in the mitochondrial membrane and cytochrome $c$ oxidase activity in adult rat myocardium. In agreement with the rise of CL during early postnatal ontogeny (Novák et al. 2006), a 2-fold increase in the content of cytochrome $c$ oxidase was found between birth and $\mathrm{d} 30$ in mitochondria of the neonatal rat heart (Škárka et al. 2003).

Although PI constitutes about $4-6 \%$ of total myocardial PL, this quantitatively minor PL plays an important role in signal transduction as a precursor of phosphatidylinositol-4,5-bisphosphate, which is split by phospholipase C (PLC) to the second messengers inositoltrisphosphate and diacylglycerol (DAG) after G-protein-coupled receptor stimulation (Nishizuka 1992). We observed maximum PI concentration on $\mathrm{d} 5$ in rat $\mathrm{LV}$ (Novák et al. 2006). Together with the increase in PI concentration on postnatal d5, a significant drop occurs in the concentration of myocardial DAG (Fig. 3), PKC activator (Hamplová et al. 2005). Thus, these results suggest an inhibition of G-protein/PLC/PKC signaling between $\mathrm{d} 2$ and $\mathrm{d} 5$, i.e. within the narrow developmental window of the hyperplasia-to-hypertrophy switch of ventricular myocytes (Li et al. 1996).

Concerning developmental changes in PS, its concentration tends to rise by $\mathrm{d} 5$, then it falls by $\mathrm{d} 10$ and does not change thereafter (Novák et al. 2006). This minor amino-PL is distributed primarily in the inner leaflet of the plasma membrane (Post et al. 1988), where it serves as the cofactor of PKC. Besides this, exposure of PS on the plasma membrane surface in the outer leaflet is one of the earliest events in apoptosis (van den Hoff et al. 2000).

The content of sphingomyelin (SM) is about $4 \%$ in newborns and declines to a half in adulthood (Novák et al. 2006). This decrease can be explained by the relative increase of mitochondrial membranes rare in SM, which is distributed mainly in the outer monolayer of the sarcolemma (Post et al. 1988) and can be concentrated in lipid membrane domains, rafts and caveolae. Moreover, SM metabolites (ceramides and sphingosine-1-phosphate) play an important role as second messengers in the regulation of cell proliferation, cell-cycle arrest, apoptosis and angiogenesis (Chatterjee et al. 2006).

\section{Phospholipid FA composition}

As demonstrated in our developmental study (Novák et al. 2006), each of the individual myocardial PL species has a characteristic proportion of FA acyl chains from birth till adulthood that might be related to its specific role in membrane function. On the other hand, FA composition in all PL undergoes similar changes during ontogeny, though their magnitude and time course differ in individual PL. As an example, Fig. 4 shows the time course of changes in the proportion of four main unsaturated FA acyl chains in PC, PE and CL from postnatal $\mathrm{d} 2$ till adulthood. Briefly, the proportion of oleic acid (18:1n-9) and arachidonic acid (20:4n-6) is relatively high while linoleic acid (18:2n-6) and docosahexaenoic acid (22:6n-3) is low in all PL shortly after birth as compared with adults. The time course in FA composition indicates that the most dynamic developmental changes in PL occur up to the suckling-toweaning transition.

Several factors may play a role in developmental changes in the FA profile of cardiac membrane PL, including nutrition, metabolic transition, hormonal changes and increasing workload. Results of dietary studies demonstrate that the FA composition of rat heart and other organs is highly responsive to the intake of n-3 and n-6 long-chain PUFA during postnatal life (Charnock et al. 1984, Suarez et al. 1996). Additionally, it was shown that reduced protein intake in pregnant rats alters the FA composition of membrane PL in the offspring after weaning (Burdge et al. 2003, Tappia et al. 2005). At the beginning of postnatal life, rats are fed exclusively by their mother's milk; hence, the FA profile of heart PL in sucklings is substantially influenced by the quality and quantity of milk fat (Berger et al. 1992, Huang et al. 1992). The composition of milk changes during lactation (Bitman et al. 1983, Bitman and Wood 1990) and the FA profile of milk triacylglycerols (TAG) shows marked interspecies differences in the chain length and SFA/PUFA ratio: whereas human milk contains a large proportion of long-chain PUFA (Bitman et al. 1983), in other species (cows, rats) the amount of SFA, MUFA and 18:2n-6 predominates (Bitman and Wood 1990, Gudmundsdottir and Gudbjarnason 1983). 
However, in our developmental study (Novák et al. 2006) as well as in that of others (Gudmundsdottir and Gudbjarnason 1983), a high amount of PUFA incorporated into myocardial $\mathrm{PC}$ and $\mathrm{PE}$ of suckling rats was observed which is not in line with the FA composition of rat milk. The high content of PUFA in PL suggests the involvement of endogenous sources of FA in myocardial PL turnover during early ontogeny. Considering the limited ability for FA synthesis (Ghosal et al. 1969) and desaturation (Brenner 1971) in the myocardium, PUFA in PL must be derived from plasma TAG and/or nonesterified FA originating from shorter chain precursors by the desaturation-elongation process in the liver (Cunnane and Chen 1992b). In line with this view, a marked quantitative increase in long-chain FA in TAG was observed in rat liver during the first postnatal week (Chen and Cunnane 1992, Cunnane and Chen 1992a). During the suckling-weaning transition (Fig. 4), $18: 2 n-6$ starts to increase, probably due to its high content in solid food. In contrast, 20:4n-6 declines gradually in all PL after weaning (Gudmundsdottir and Gudbjarnason 1983, Novák et al. 2006). The high proportion of 20:4n-6 in PL of rat myocardium after birth is in line with the results of Decrok et al. (2002) who show that the main PUFA in myocardial PL is $20: 4 n-6$ on $d 2$ post-hatching in king penguin, although there is a preponderance of $n-3$ PUFA in the yolk. The increase in $20: 4 n-6$ and 22:6n-3 proportion in myocardial PL observed just after birth copy closely the alterations in FA composition in cardiac membranes after the administration of catecholamines (Gudbjarnason 1989, Gudbjarnason and Benediktsdottir 1996). We suppose that this membrane modification reflects an early response of the heart to stress connected with the transition from fetal to neonatal life. During adulthood and aging, from the $3^{\text {rd }}$ till the $23^{\text {rd }}$ month, the level of 18:2n-6 decreases in PC and that of $20: 4 n-6$ increases in $\mathrm{PC}$ and $\mathrm{PE}$ of the rat heart which coincides with the down-regulation of $\beta$-adrenoceptors (Benediktsdottir et al. 1995, Gudbjarnason and Benediktsdottir 1996).

The gradual elevation of the $22: 6 n-3$ content in all PL during the suckling period observed in our study (Novák et al. 2006) and by others (Ghebremeskel et al. 1999, Gudmundsdottir and Gudbjarnason 1983), cannot be explained by nutritional intake alone. The content of this PUFA in mother's milk even decreases during the development of rats (Guesnet et al. 1997) and human neonates (Gibson and Kneebone 1981). This process of hormonal maturation during postnatal development offers
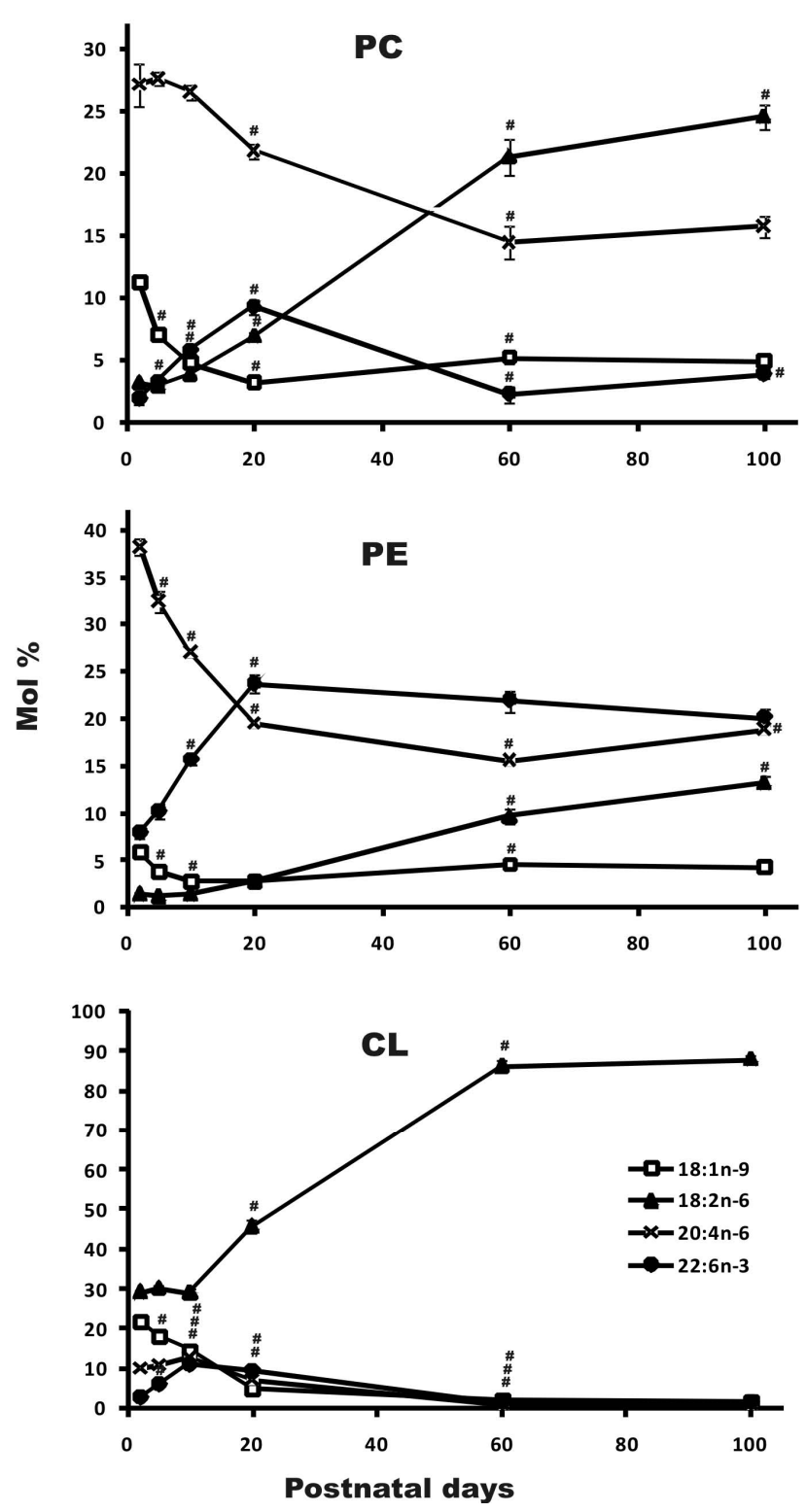

Fig. 4. Time course (postnatal days 2, 5, 10,20,60 and 100) of changes in the proportion of $18: 1 n-9$ (oleic acid), 18:2n-6 (linoleic acid), 20:4n-6 (arachidonic acid) and 22:6n-3 (docosahexaenoic acid) in PC (phosphatidylcholine), PE (phosphatidylethanolamine), CL (cardiolipin) (adapted from Novák et al. 2006). Values are means \pm S.E.M. from 5 experiments in each group. $\# \mathrm{p}<0.05$, significant difference vs. previous stage.

a more acceptable explanation for the 22:6n-3 increase. The plasma level of thyroid hormones in the rat increases gradually until the third postnatal week (Vigouroux 1976), resembling the time course of the increase in 22:6n-3 in cardiac PL (Fig. 4). Moreover, the increase in $22: 6 n-3$ in the neonatal heart can even accelerate in hyperthyroidism (see further) (Hamplová et al. 2003). The developmental rise of $22: 6 n-3$ can be also related to increasing adrenergic responsiveness of the developing 
rat heart (Novotný et al. 1999). Stimulation of the heart by catecholamines leads to an increase of $22: 6 n-3$ in myocardial PL of adult rats (Benediktsdottir et al. 1995, Gudbjarnason and Benediktsdottir 1996). Similar remodeling of myocardial FA composition was observed in response to different stress conditions, such as exposure of immature (Novák et al. 2004) or adult rats to chronic hypoxia (Ježková et al. 2002) or to systemic pressure overload (Nováková et al. 2002) (see further text). Gudbjarnason et al. (1978) described the positive correlation between heart rate of mammals, ranging from mice to whales, and 22:6n-3 content in their myocardial PL. Similarly, Hulbert et al. (2002) reported a substantial allometric decline in 22:6n-3 content in PL of the heart, skeletal muscle, liver and kidney with increasing body mass. The relationship mentioned above supports the hypothesis that the relative amount of 22:6n-3 can act as a membrane pacemaker for metabolic activity. Although its mode of action is not quite clear, the fundamental role of 22:6n-3 in membranes of many tissues is evident. This unique PUFA is known to readily incorporate into PL and thus significantly alter the basic properties of membranes, including fluidity and permeability. Recently, 22:6n-3 has been proposed to play an important role in the formation of lipid rafts (Shaikh et al. 2003) and thereby in a modification of function of proteins for which these regions provide a platform (Wassall et al. 2004). Many dietary studies suggest that the replacement of $n-6$ by $n-3$ PUFA in membrane PL might have beneficial effects on the heart and reduce the risk of sudden death (Durot et al. 1997).

It should be stressed that the FA profile in CL shifts most remarkably among membrane PL during heart ontogeny. Whereas in CL of newborns, besides 18:2n-6 also 18:1n-9 and 20:4n-6 acyl chains are present (Fig. 4), (Novák et al. 2006), an 18:2n-6-enriched CL is found in the adult heart, where $18: 2 \mathrm{n}-6$ constitutes $80-90 \%$ of CL acyl chains and other chains are quite minor (Hoch 1992). Fig. 4 shows that 18:2n-6 and 20:4n-6 levels do not change during the suckling period and 18:2n-6 steeply raises later, followed by a decline of $20: 4 n-6$. Both acyl chains maintain the constant level in the heart of 2- and 3-month-old rats. Lee et al. (2006) demonstrated that the FA composition of CL alters dramatically again with aging: the amount of 18:2n-6 decreases in favor of 20:4n-6 and 22:6n-3 in 24-month-old rats as compared with 4-month-old ones. It is believed that the acyl chain specificity of CL can be attained via remodeling, as the enzymes responsible for its de novo synthesis are not acyl-group specific (Rustow et al. 1989). The remodeling is achieved through coordinated biosynthetic and remodeling pathways (Fig. 1) (Hauff and Hatch 2006, Li et al. 2007, Schlame and Ren 2006). Tetralinoleoyl-CL is the most abundant of CL species in mammalian heart, its maximum molecular symmetry being crucial for tight interactions of CL with mitochondrial proteins (Schlame et al. 2005). In line with this assumption, cytochrome $c$ oxidase was stimulated most effectively by $\mathrm{CL}$ rich in 18:2n-6 in reconstituted vesicles (Yamaoka-Koseki et al. 1991). In agreement with our developmental study on the rat heart, Cheng et al. (2008) observed a similar fatty acyl pattern in CL of the rat brain during the first few days after birth. Surprisingly, the low level of 18:2n-6 (about $10 \mathrm{~mol} \%$ ) persisted in the brain CL of adult rats in contrast with the high content of 18:2n-6 in CL of most mammalian tissues including the heart (Novák et al. 2006).

\section{Effect of excessive workload on postnatal phospholipid remodeling}

\section{Systemic pressure overload}

In various forms of systemic hypertension, LV hypertrophy is considered as an adaptive response aiming to compensate for increased afterload and maintain normal hemodynamic functions. Hypertrophy involves specific qualitative alterations in gene expression as well as in cardiac cell phenotype (Dambrin et al. 1994, Ritter and Neyses 2003). Although the initial outcome is a compensatory growth of the heart, the excessive or longlasting stimulus may lead to congestive heart failure. Myocardial adaptation to increased workload includes structural and functional alterations of cell membranes which is well documented for both protein (Moalic et al. 1993, Zheng et al. 1996) and lipid components (Mrnka et al. 1996, Reibel et al. 1986). Numerous results, obtained mostly with isolated cardiomyocytes, indicate that hydrolytic products derived from membrane PL by the action of phospholipases play an important role as second messengers in signal transduction involved in the stimulation of cell growth and proliferation (Dorn and Force 2005, Tappia 2007). In view of these observations, the remodeling of membrane PL induced by pressure overload during early ontogeny may influence the postnatal growth and other physiological characteristics of the developing heart.

In our experiments, we used a model of pressure overload induced in neonatal rats ( $\mathrm{d} 2$ or $\mathrm{d} 6$ ) by the 
A.

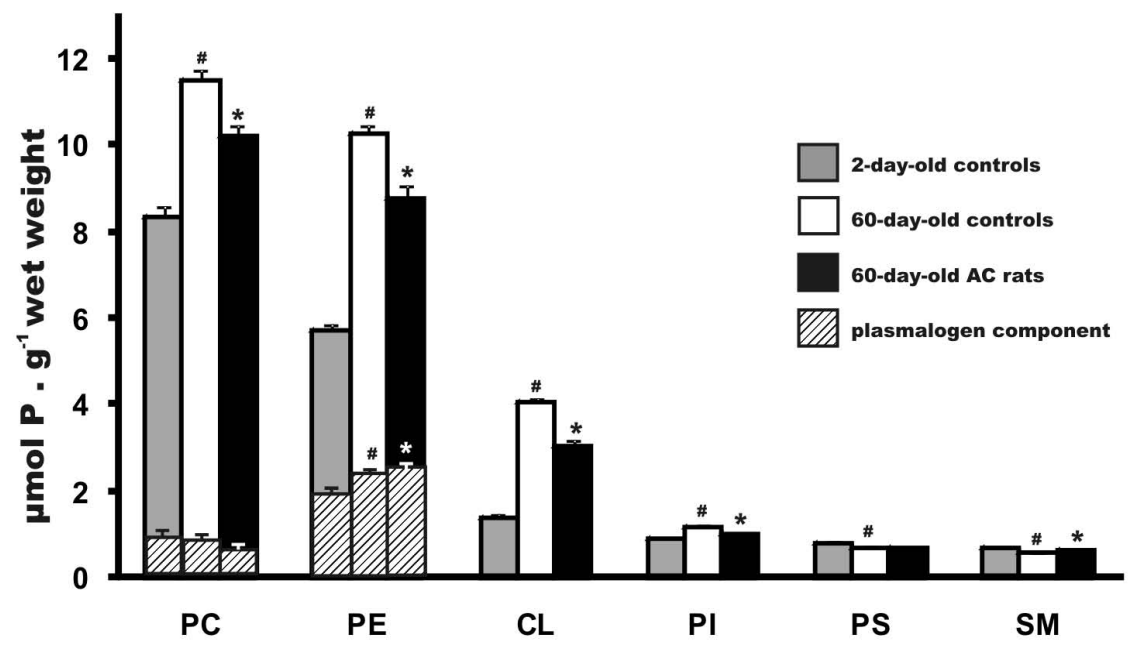

B.

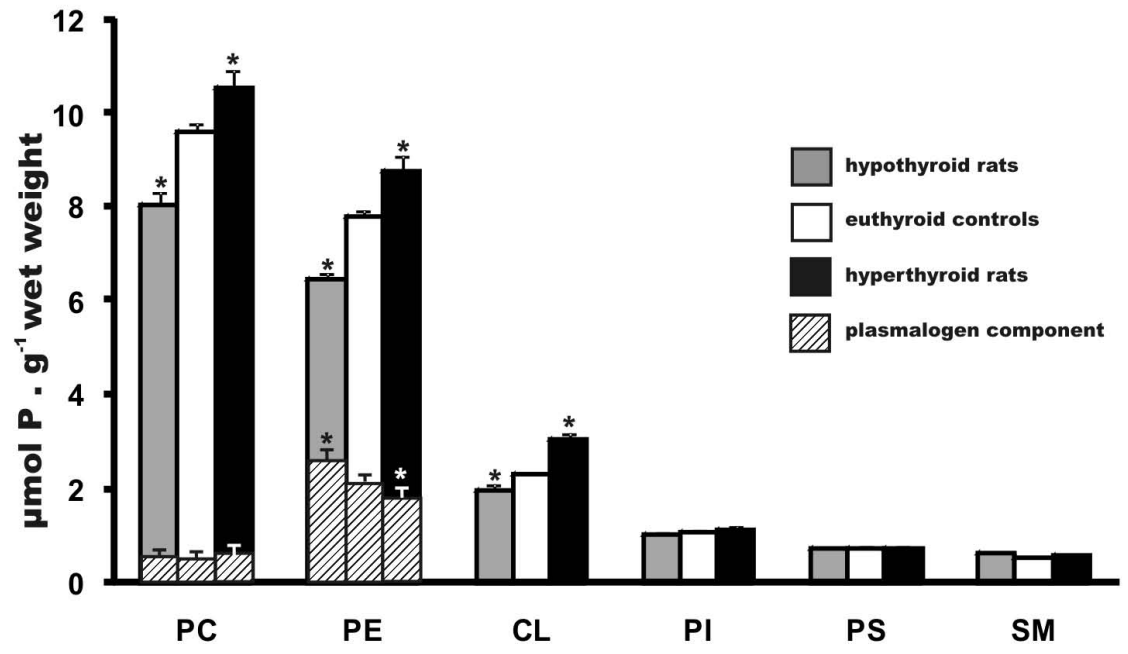

Fig. 5. A. Concentration of $P C$ (choline phosphoglycerides), PE (ethanolamine phosphoglycerides), CL (cardiolipin), PI (phosphatidylinositol), PS (phosphatidylserine), SM (sphingomyelin) in left ventricles of 2-day- and 60-day-old controls and 60-day-old aorta-constricted (AC) rats (AC was induced on postnatal day 2). Values are means \pm S.E.M. from 5 experiments in each group. $\# p<0.05,60$-day-old vs. 2day-old controls; $* p<0.05, A C$ vs. 60-day-old controls (adapted from Mrnka et al. 1996). B. Phospholipid concentration in left ventricles of 21day-old rats in different thyroid states. Values are means \pm S.E.M. from 5 experiments in each group. $* p<0.05$, hypothyroid or hyperthyroid rats vs. euthyroid controls (adapted from Hamplová et al. 2003). abdominal aorta constriction (AC) as described earlier (Koláŕ et al. 1998). This model allows adaptive responses of the myocardium which is still in the proliferative phase of the ventricular myocyte growth (Clubb and Bishop 1984, Sedmera et al. 2003). AC in neonatal rats leads to a pronounced increase in the LV mass and to a moderate increase in the right ventricle (RV) mass during maturation (LV/BW by $60 \%$, RV/BW by $20 \%$ ), indicating the transition from the compensatory phase of hypertrophy to heart failure. Concentrations of PC, PE, CL and PI are lower in the LV (by $11 \%, 14 \%, 24 \%$ and $15 \%$, respectively) of 60 -d-old AC rats as compared with age-matched controls (Mrnka et al. 1996). The concentrations of SM and PLPE increase (by $10 \%$ and $8 \%$, respectively) (Fig. 5A). The decrease in the concentration of main PL species (especially CL) reflects the impaired development of membrane structures (predominantly mitochondria) as documented by quantitative electron microscopy in AC hearts (Page and McCallister 1973).
Figure 6 shows changes in the main PUFA profile induced by pressure overload in PC, PE and CL of the LV. In PC, the proportion of 18:2n-6 decreases and it is compensated by the increase of $20: 4 n-6$ and $22: 6 n-3$ PUFA in LV of 60-d-old AC vs. age-matched controls. In PE of AC rats, the proportion of 18:2n-6 decreases, while the proportion of $22: 6 n-3$ increases, compared with the controls. In CL of AC rats, the proportion of 16:0, 18:0 and 18:1n-7 increases (not shown) while 18:2n-6 decreases compared with the controls (Fig. 6). Alterations in PL concentration and FA acyl chain profile in the RV were similar but less pronounced than in the LV. The comparative analysis of 60-day-old intact and agematched sham-operated controls did not show any difference in the concentration of PL and their FA profiles (not shown).

A similar PL remodeling in pressure overload hypertrophy induced by AC has been well documented in adult rats. The reduction in the proportion of $18: 2 n-6$ and increased accumulation of $22: 6 n-3$ in most of PL are 
Aorta constriction
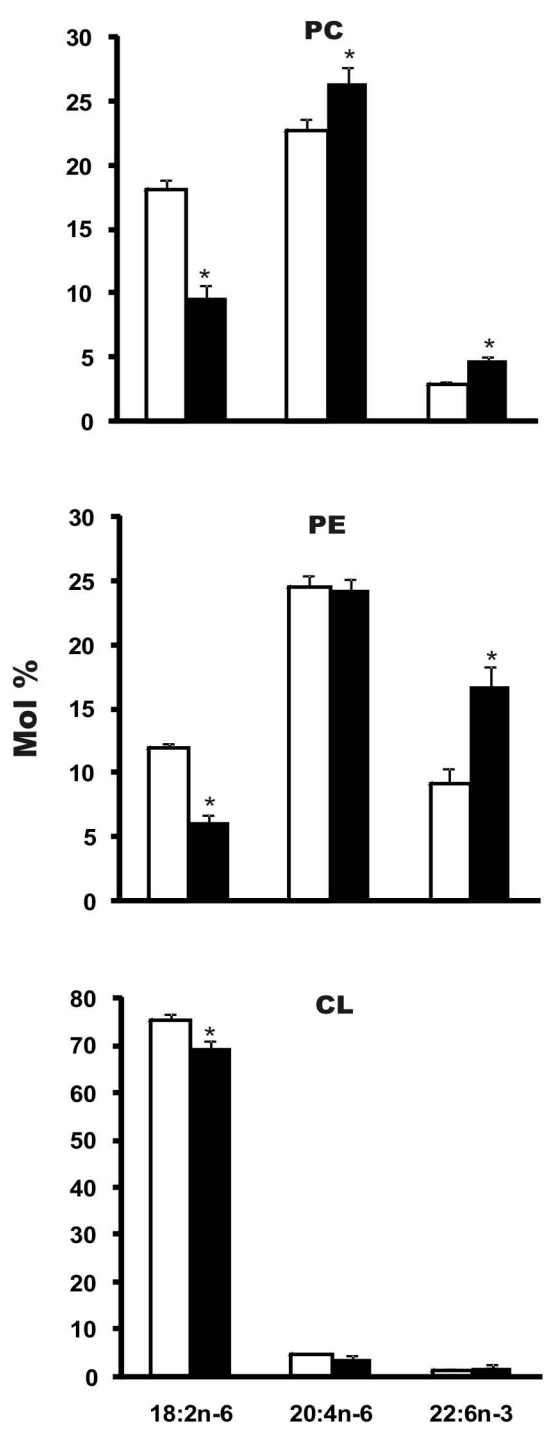

Chronic hypoxia
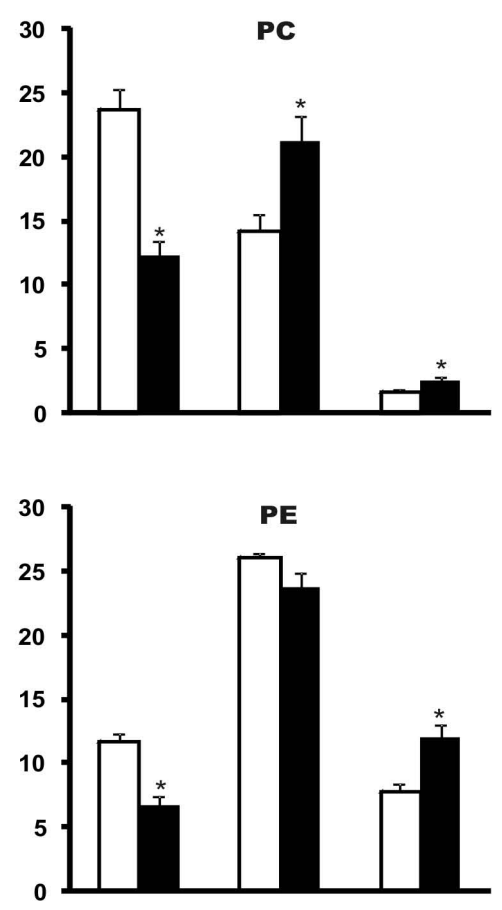

CL
Fig. 6. Changes in proportions of $18: 2 n-6$ (linoleic acid), 20:4n-6 (arachidonic acid) and 22:6n-3 (docosahexaenoic acid) in PC (phosphatidylcholine), PE (phosphatidylethanolamine) and $\mathrm{CL}$ (cardiolipin) in the left ventricle of 60-day-old aorta-constricted rats (unpublished data) and in the right ventricle of 40-day-old chronically hypoxic rats (adapted from Novák et al. 2004); controls (white columns), load (black columns). Values are means \pm S.E.M. from 5 experiments in each group. * $\mathrm{p}<0.05$, significant difference vs. corresponding controls.

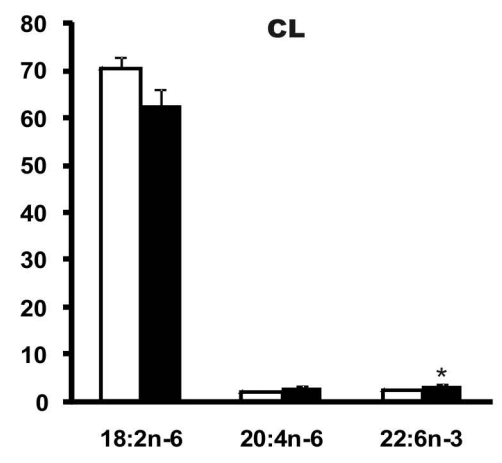

nearly identical with those observed in our model of pressure overload induced just after birth. In contrast, the myocardial concentration of $\mathrm{CL}$ and proportion of 20:4n-6 in PC in adults are not influenced by AC (Reibel et al. 1986). Recently, considerable attention has been paid to CL remodeling in human and experimental heart failure. It has been proposed that pathological remodeling of CL (e.g. loss of tetralinoleoyl-CL and the rise in CL species containing $18: 1 n-9,20: 4 n-6$ and $22: 6 n-3)$ relates to impaired mitochondrial function and thereby may play a role in the initiation of heart failure (Heyen et al. 2002, Sparagna et al. 2007). The results presented in Fig. 6A point to two interesting observations: (i) loss of 18:2n-6 in $\mathrm{CL}$ is negligible compared to that of $\mathrm{PC}$ and $\mathrm{PE}$, and (ii) the decline of $18: 2 \mathrm{n}-6$ in $\mathrm{PC}$ and $\mathrm{PE}$ is compensated by incorporation of 20:4n-6 in PC and 22:6n-3 in PC and PE. Moreover, our results suggest that this phenomenon occurs both in pressure-overloaded hearts (AC) and in hearts of rats exposed to chronic hypoxia (Fig. 6). Xu et al. (2003) demonstrated a CL remodeling pathway in rat liver mitochondria that involves the CoA-independent transfer of 18:2n-6 acyl chains by the transacylation reaction directly from $\mathrm{PC}$ or $\mathrm{PE}$ to monolyso-CL. This energy-independent transacylation exhibits a clear specificity for the 18:2n-6 acyl chain and was shown to completely convert tetraoleoyl-CL to tetralinoleoyl-CL. These data suggest the possible way how to keep tetralinoleoyl-CL level and symmetry under conditions of decreased energy production in the overloaded heart. Thus, we suppose that PC and PE could serve as the storage of 18:2n-6 for regeneration of fully functional CL in the myocardium subjected to increased load from the early postnatal period. Yamashita et al. (1997) observed in the liver a CoA-independent transacylase, which 
catalyzes the transfer of C20 and C22 PUFA from diacylPL to various lyso-PL. This observation could help to explain the increased accumulation of 20:4n-6 and 22:6n3 into PC and PE observed under various stress conditions.

\section{Chronic hypoxia}

Chronic myocardial hypoxia is the major pathophysiological feature of various cardiopulmonary diseases, such as chronic obstructive pulmonary disease and cyanotic congenital heart defects. It is also naturally present in fetuses and in individuals living at high altitude (Oštádal and Kolár 2007). It was shown that the adaptation to chronic hypoxia leads to a variety of morphological, biochemical and functional changes in order to maintain homeostasis with minimum energy expenditure (Oštádal et al. 1999). Chronic hypoxia affects both ventricles that need to adapt to decreased oxygen availability but the RV must in addition cope with increased afterload due to pulmonary hypertension. Pulmonary hypertension, RV hypertrophy and myocardial remodeling are the characteristic features of chronic hypoxia. Besides the potentially adverse influence on the cardiopulmonary system, it is well established that the heart adapted to chronic hypoxia exhibits an increased tolerance to acute ischemic injury manifested as a reduction of myocardial infarct size, improvement of post-ischemic contractile dysfunction and limitation of life-threatening ventricular arrhythmias (Kolář and Oštádal 2004, Oštádal and Kolář 2007).

We have shown that, in addition to the remodeling of extracellular matrix, myofibrillar proteins and metabolic enzymes (Oštádal et al. 1995, Pelouch et al. 1993, Bass et al. 1989), the remodeling of cardiac membrane PL also takes place in the heart of both neonatal (Novák et al. 2004, Oka et al. 2008) and adult hypoxic rats (Balková et al. 2009, Hlaváčková et al. 2007, Ježková et al. 2002). Rats exposed to intermittent hypobaric hypoxia $(7000 \mathrm{~m}, 8 \mathrm{~h} /$ day) from postnatal $\mathrm{d} 4$ till d40 exhibit RV hypertrophy (36\%) while LV hypertrophy is less pronounced. The concentration of myocardial PL is unchanged except for a slight but significant decrease in mitochondrial $\mathrm{CL}$ in the LV (by $9 \%$ ). On the other hand, our study on adult rats adapted to the same hypoxic conditions demonstrates a greater effect on CL, namely in the RV (decrease by $19 \%$ ) (Ježková et al. 2002). The relative stability of membrane PL concentration in newborn hearts exposed to chronic hypoxia is in good agreement with other studies indicating higher resistance of newborn rat heart to oxygen deprivation compared with adults (Oštádal et al. 1999). The absence of a decrease in the concentration of major PL despite a significant rise in the heart mass, which was observed in young rats, suggests that hypertrophy induced by intermittent hypoxia is accompanied by a proportional increase in the synthesis of membrane PL. In contrast, the cardiomegaly induced by LV pressure overload in rats during the early postnatal period might be an example of disproportion between the synthesis of myocardial proteins and PL, resulting in a decrease in PL concentration (Mrnka et al. 1996).

The adaptation to chronic hypoxia leads to a substantial decrease in 18:2n-6 proportion, which is compensated by an increase in 20:4n-6 and 22:6n-3 acyl chains in both PC and PE. In CL, chronic hypoxia causes an increase in the 22:6n-3 acyl chain proportion (Fig. 6). No left-to-right ventricle difference in FA composition of $\mathrm{PC}$ and PE is observed in young rats, in agreement with the previous report on adult rats adapted to the same hypoxic conditions (Ježková et al. 2002). It may be suggested that these changes are due to hypoxia itself rather than due to increased RV afterload.

During exposure to hypoxia, numerous metabolic pathways can participate in the remodeling of FA composition in membrane PL; the deacylationreacylation cycle where $\mathrm{PLA}_{2}$ and acyltransferases cooperate, desaturation-elongation processes, and PL de novo synthesis belong to these pathways. The increase in the 20:4n-6/18:2n-6 ratio might be caused by activation of the desaturation-elongation pathway of 18:2n-6. The presence of both $\Delta-6$ desaturase and elongase in cardiac myocytes was reported (Lopez Jimenez et al. 1993). In our study (Novák et al. 2004), we have shown that the decreased content of 18:2n-6 was compensated by the elevation of 22:6n-3, which is a poorer substrate for $\mathrm{PLA}_{2}$ than n-6 PUFA (Nalbone et al. 1990). Moreover, acylCoA synthetase with preferential affinity for 22:6n-3 was found in cardiac tissue (Bouroudian et al. 1990). Kawaguchi et al. (1991) reported that hypoxia leads to PL breakdown due to the activation of $\mathrm{PLA}_{2}$. CoAindependent transacylase with high specificity for C20 and $\mathrm{C} 22$ unsaturated acyl chains (mentioned in connection with LV pressure overload) should be also taken into consideration (Yamashita et al. 1997). We can speculate that increased oxidative stress could play a role in the process of membrane PL remodeling. Chronic hypoxia is associated with increased myocardial oxidative stress as evidenced by marked lipid 
peroxidation (Kolář et al. 2007, Yoshikawa et al. 1982). It was shown that $\mathrm{PLA}_{2}$ preferentially hydrolyzes damaged FA acyl chains from PL, thereby allowing their repair by the deacylation-reacylation process and the protection of membranes against further oxidative damage (De Windt et al. 1998).

\section{Thyroid states}

Thyroid hormones (TH) are important players in the control of ontogenetic development of cardiac membrane structures. TH appear in the plasma of rats on prenatal day 18 (Pic and Bouquin 1985) and reach their maximum levels in the third postnatal week (Vigouroux 1976). It has been well documented that hypothyroidism slows down the postnatal maturation of ventricular tissue whereas hyperthyroidism accelerates this process (Dieckman and Solaro 1990, Hoch 1988, Simonides and van Hardeveld 1987). In the immature rat myocardium among others, TH regulate the development of the coronary capillary network (Heron et al. 1997), early maturation of cardiac adrenergic signaling (Novotný et al. 1999, Whitsett et al. 1982), maturation of $\mathrm{Ca}^{2+}$ handling (Černohorský et al. 1998, Kolář et al. 1992, Wibo et al. 1995) and also the PL remodeling of cardiac membranes (Hamplová et al. 2003, Kumar and Chaudhuri 1993, Vasdev et al. 1977).

We examined the effect of hypo- and hyperthyroidism on the PL composition in the developing rat heart. The hypothyroid state was induced by propylthiouracil (PTU) in drinking water given to nursing mothers from the postnatal $\mathrm{d} 2$ till $\mathrm{d} 21$. Hyperthyroidism was produced by daily injection of triiodo-L-thyronine $\left(\mathrm{T}_{3}\right)$ to newborns in the same period of time (Hamplová et al. 2003). Hypothyroidism decreases the relative weights of the LV and RV by $22 \%$ and $29 \%$, respectively, compared with euthyroid animals on postnatal $\mathrm{d} 21$. Fig. 5B shows the decrease in the concentration of major PL, suggesting that normal maturation of cardiac membranes is delayed in hypothyroidism (Hamplová et al. 2003). The reason for the slowing down of membrane PL maturation in hypothyroid rats may be either the nutrition deficit as hypothyroid mothers are hypolactating (Babický and Nováková 1985, Zeisel et al. 1986), or cardiac hypofunction with low heart rate, low velocity of contraction, and last but not least a lack of stimulatory effect of $\mathrm{TH}$ on the expression and activity of enzymes involved in PL metabolism (Hoch 1988, Taylor et al. 2002).

In contrast, we found an increase in the relative weights of the LV and RV (by $55 \%$ and $80 \%$, respectively) and an increase in the concentration of major $\mathrm{PL}$ in the hyperthyroid rat myocardium on postnatal d21 (Fig. 5B). This is in line with the observation that hyperthyroidism also stimulates biosynthesis of CL and PC in the adult heart (Cao et al. 1995, Limas 1980). Moreover, the maturation of ventricular membrane structures is accelerated in hyperthyroid neonatal rats as demonstrated by Jarkovská et al. (1994). It has been shown that in hyperthyroid rats the mitochondrial contribution to cell volume increases and the volume of myofibrils remains constant (McCallister and Page 1973) while in euthyroid rats, the contribution of myofibrils and mitochondria to myocardial cell volume increases proportionally during postnatal development (Page et al. 1974). In addition, the elevated number and size of mitochondria in the cardiac muscle of hyperthyroid adults in comparison with euthyroid controls was reported (Page and McCallister 1973). Accordingly, we observed a markedly increased relative proportion of $\mathrm{CL}$ as a marker of preferential growth of mitochondrial structures in hyperthyroid immature myocardium (Hamplová et al. 2003). Both altered thyroid states also change the proportion of PLPE: hypothyroidism increases and hyperthyroidism decreases it, compared with euthyroid controls. Because plasmalogens are predominant PL of cardiac sarcolemma and their content is relatively low in mitochondria (Post et al. 1988), the observed differences may suggest that the proportion of mitochondrial to extramitochondrial membranes differs in the two altered thyroid states (Fig. 5B).

In our study (Hamplová et al. 2003), both hypoand hyperthyroidism caused marked changes in FA acyl composition of individual PL in comparison with euthyroid controls (Fig. 7). Hypothyroidism maintains similar PL acyl chain composition in ventricles of 21day-old rats as in euthyroid rats just after birth (Berger et al. 1992, Ghebremeskel et al. 1999, Gudmundsdottir and Gudbjarnason 1983), except for 18:2n-6, the content of which is higher in all PL compared with the euthyroid group. Similarly, the content of 18:2n-6 increases in cardiac mitochondria of hypothyroid adult rats (Hoch 1982). A possible explanation of the rise in $18: 2 n-6$ and concomitant decrease in the $20: 4 n-6 / 18: 2 n-6$ ratio is the inhibition of $\Delta-6$ desaturase activity by the lack of $\mathrm{TH}$. The diminished $\Delta-6$ desaturase activity, the rate-limiting step in the conversion of $18: 2 n-6$ to $20: 4 n-6$, was observed in the liver of hypothyroid adult rats (Faas and 
Carter 1982). The remodeling of FA composition after PTU treatment led to a decrease of the unsaturation index (UI) in PC. This decrease was caused by a redistribution of high unsaturated FA acyl chains in favor of the less unsaturated ones due to a marked decrease in the proportion of 22:6n-3 as compared with euthyroid controls (Hamplová et al. 2003) (Fig. 7). Pehowich (1995) reported a similar decrease of the 22:6n-3 content in cardiac mitochondria of hypothyroid rats. Decreased UI is also observed in cardiac mitochondria from hypothyroid adult rats (Hoch 1982) and in the sarcolemma from hypothyroid adult rabbits (Szymanska et al. 1991). In hyperthyroid hearts, a decreased n-6/n-3 PUFA ratio in PC and PE is caused by the decrease in 20:4n-6 and increase in 22:6n-3 contents. Enhanced conversion of 20:4n-6 to prostaglandin E2 may contribute to the lower 20:4n-6 level in PL of hyperthyroid hearts (Gudbjarnason 1975). The changes in the balance between n-6 and n-3 PUFA may have significant biological implications because eicosanoids derived from these two PUFA series exert adverse biological activities (Dimitrow and Jawien 2009).

\section{Concluding remarks}

Table 1 shows the changes in 20:4/18:2, n-6/n-3 ratios and UI in rat heart during postnatal development (d2, d21, d40 and d60) and effects of additional workload (hyperthyroidism, chronic hypoxia and aorta constriction). The gradual decline of 20:4/18:2 between $\mathrm{d} 2$ and $\mathrm{d} 40$ occurs in PC, PE and CL due to the rise in 18:2n-6 and fall in 20:4n-6 contents. The n-6/n-3 ratio in $\mathrm{PC}$ and PE decreases till $\mathrm{d} 21$ mainly due to the significant increase in $n-3$ PUFA proportion. In contrast, the remarkable rise in the $n-6 / n-3$ ratio appears on $d 40$ in all PL, mainly due to the increase in the $18: 2 n-6$ proportion. The value of UI decreases on $\mathrm{d} 40$ and does not change thereafter. Hyperthyroidism lowers the 20:4/18:2 ratio because of the increase in 18:2n-6 in all PL. On the other hand, due to the pronounced drop in 18:2n-6, chronic hypoxia and LV pressure overload increase the 20:4/18:2 ratio in $\mathrm{PC}$ and $\mathrm{PE}$. Concerning the influence of additional workload, UI increased only in PE of pressureoverloaded (AC) hearts. These results show that the period between postnatal $\mathrm{d} 21$ and $\mathrm{d} 40$ is characterized by metabolic conversion from suckling-weaning to the adolescence accompanied by nutritional transition from high-fat mother's milk to carbohydrate-rich solid food with a high 18:2n-6 content. In this period, the

\section{Thyroid states}

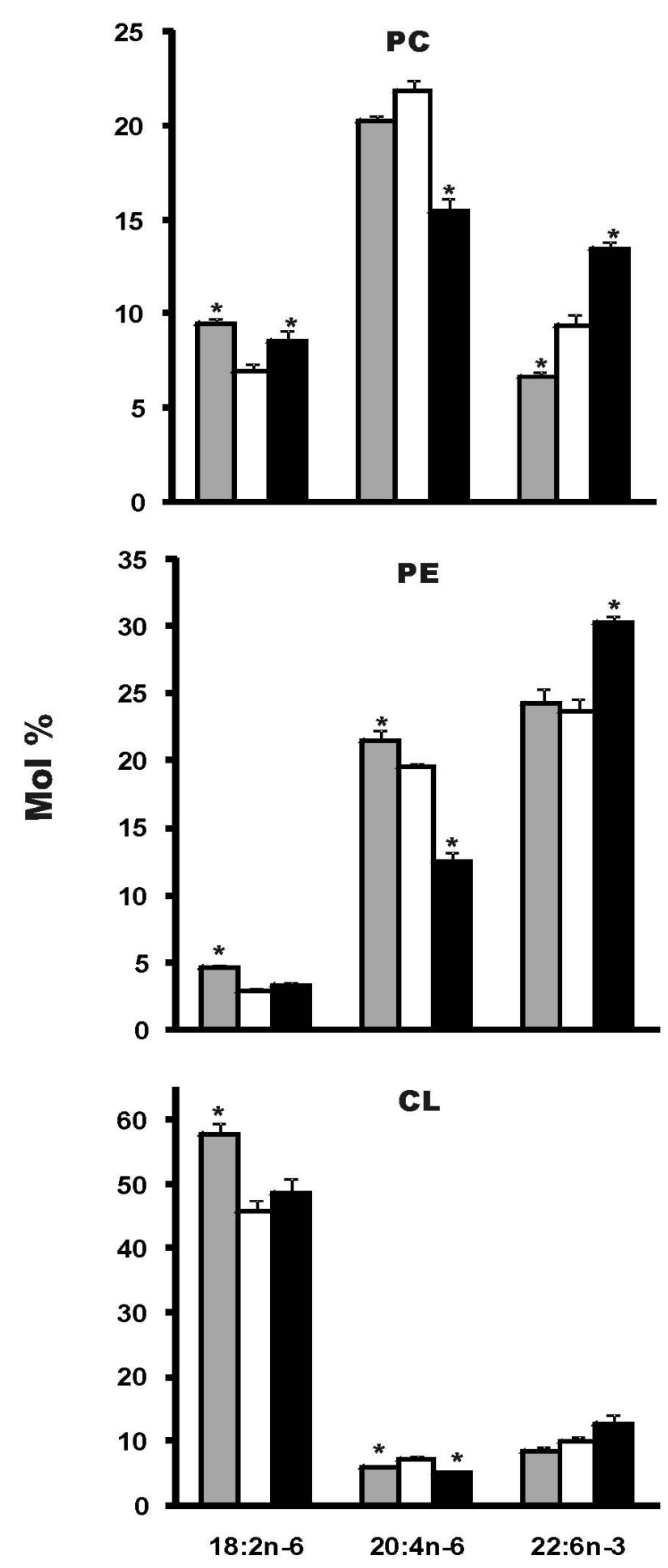

Fig. 7. Proportion of $18: 2 n-6$ (linoleic acid), $20: 4 n-6$ (arachidonic acid) and 22:6n-3 (docosahexaenoic acid) in PC (phosphatidylcholine), PE (phosphatidylethanolamine) and $\mathrm{CL}$ (cardiolipin) in left ventricles of hypothyroid (grey columns), euthyroid (white columns) and hyperthyroid (black columns) 21day-old rats (adapted from Hamplová et al. 2003). Values are means \pm S.E.M. from 5 experiments in each group. $* \mathrm{p}<0.05$, hypothyroid or hyperthyroid rats vs. euthyroid controls. 
Table 1. Effect of increased workload on $20: 4 / 18: 2$ and $n-6 / n-3$ ratios and unsaturation index in myocardial phospholipids.

\begin{tabular}{cccccccc}
\hline & $\mathbf{d} 2$ & $\mathbf{d 2 1}$ & $\mathbf{d 2 1}-\mathbf{T}_{\mathbf{3}}$ & $\mathbf{d 4 0}$ & $\mathbf{d 4 0 - C H}$ & $\mathbf{d 6 0}$ & $\mathbf{d 6 0 - A C}$ \\
\hline $\boldsymbol{P C}$ & & & & & & & \\
$20: 4 / 18: 2$ & $8.55 \pm 0.37$ & $3.19 \pm 0.19^{\#}$ & $1.82 \pm 0.09^{*}$ & $0.63 \pm 0.09^{\#}$ & $1.83 \pm 0.24^{*}$ & $1.15 \pm 0.09$ & $2.75 \pm 0.21^{*}$ \\
$n-6 / n-3$ & $10.69 \pm 1.30$ & $2.17 \pm 0.13^{\#}$ & $1.43 \pm 0.11^{*}$ & $15.9 \pm 2.67^{\#}$ & $7.38 \pm 1.21^{*}$ & $10.40 \pm 0.67^{\#}$ & $5.27 \pm 0.20^{*}$ \\
$U I$ & $162.0 \pm 11.3$ & $195.4 \pm 5.2^{\#}$ & $193.3 \pm 1.6$ & $135.0 \pm 4.5^{\#}$ & $153.7 \pm 10.2$ & $165.6 \pm 3.2$ & $177.6 \pm 7.6$ \\
& & & & & & & \\
$\boldsymbol{P} \boldsymbol{E}$ & & & & & & & \\
$20: 4 / 18: 2$ & $27.79 \pm 3.66$ & $7.31 \pm 0.63^{\#}$ & $3.97 \pm 0.29^{*}$ & $2.25 \pm 0.12^{\#}$ & $3.63 \pm 0.30^{*}$ & $2.06 \pm 0.16$ & $3.98 \pm 0.57^{*}$ \\
$n-6 / n-3$ & $4.11 \pm 0.39$ & $0.81 \pm 0.03^{\#}$ & $0.49 \pm 0.02^{*}$ & $3.93 \pm 0.39^{\#}$ & $2.09 \pm 0.23^{*}$ & $3.49 \pm 0.36$ & $1.66 \pm 0.11^{*}$ \\
$U I$ & $268.3 \pm 5.9$ & $268.9 \pm 6.2$ & $267.8 \pm 5.2$ & $197.5 \pm 3.5^{\#}$ & $207.1 \pm 4.9$ & $200.5 \pm 9.2$ & $235.3 \pm 9.4^{*}$ \\
$\boldsymbol{C L}$ & & & & & & & \\
$20: 4 / 18: 2$ & $0.35 \pm 0.03$ & $0.16 \pm 0.01^{\#}$ & $0.10 \pm 0.01^{*}$ & $0.03 \pm 0.01^{\#}$ & $0.05 \pm 0.01$ & $0.06 \pm 0.01$ & $0.05 \pm 0.03$ \\
$n-6 / n-3$ & $7.36 \pm 0.35$ & $5.16 \pm 0.60$ & $4.25 \pm 0.71$ & $25.83 \pm 2.76^{\#}$ & $16.78 \pm 1.72^{*}$ & $48.60 \pm 7.05^{\#}$ & $31.53 \pm 5.96$ \\
$U I$ & $208.0 \pm 4.7$ & $233.1 \pm 6.8$ & $238.9 \pm 6.4$ & $180.0 \pm 4.6^{\#}$ & $177.8 \pm 5.8$ & $188.1 \pm 1.9$ & $181.4 \pm 2.6$ \\
\hline
\end{tabular}

Values are means \pm S.E.M. from 5 experiments in each group. PC (phosphatidylcholine), PE phosphatidylethanolamine), $\mathrm{CL}$ (cardiolipin), d - postnatal day, $\mathrm{T}_{3}$ - hyperthyroid group (left ventricle, d2-d21, adapted from Hamplová et al. 2003), $\mathrm{CH}-\mathrm{chronic}$ hypoxia (right ventricle, d4-d40, adapted from Novák et al. 2006), AC - aorta constriction (left ventricle, d2-d60, unpublished data), UI - unsaturation index calculated as mol\% of individual unsaturated FA multiplied by the number of double bonds. ${ }^{\#} \mathrm{p}<0.05$ vs. previous stage, $* \mathrm{p}<0.05$ vs. corresponding age-matched controls.

unsaturation of the membrane lipid bilayer decreases as evidenced by the observed decrease in UI, caused by the fall of 20:4/18:2 and rise in $n-6 / n-3$ ratios in all PL species. The considerably lower polyunsaturation of all PL on d40 may be explained by high proportion of mitochondrial membranes in the adult heart compared to the neonatal one. In agreement, Thesalouhidou et al. (2006) have shown that mitochondrial PL from skeletal muscle are significantly less polyunsaturated than those from the whole tissue. Lower UI in adulthood may contribute to higher selective resistance of mitochondrial PL toward oxidative stress.

Our comparative analysis shows that both the physiological increase of the load during normal postnatal development and additional workload imposed by various interventions early after birth lead to a decrease in the $n-6 / n-3$ ratio, i.e. an increase of n-3 PUFA at the expense of n-6 PUFA in all myocardial PL. This change can be considered as a general adaptive response of cardiac membranes to stress.

\section{Conflict of Interest}

There is no conflict of interest.

\section{Acknowledgements}

Supported by the Ministry of Education, Youth and Sports of the Czech Republic grants No. 0021620858, 1M0510 and grant AV0Z 20110509.

\section{References}

BABICKÝ A, NOVÁKOVÁ V: Influence of thyroxine and propylthiouracil administration on the intake of maternal milk in sucklings of the laboratory rat. Physiol Bohemoslov 34: 193-199, 1985.

BABICKÝ A, OŠŤÁDALOVÁ I, PǍ̌ÍZEK J, KOLÁŘ J, BÍBR B: Onset and duration of the physiological weaning period in infant rats reared in nests of different size. Physiol Bohemoslov 22: 449-456, 1973.

BALKOVÁ P, JEŽKOVÁ J, HLAVÁČKOVÁ M, NECKÁŘ J, STAŇKOVÁ B, KOLÁŘ F, NOVÁK F, NOVÁKOVÁ $O$ : Dietary polyunsaturated fatty acids and adaptation to chronic hypoxia alter acyl composition of serum and heart lipids. Br J Nutr 102: 1297-1307, 2009. 
BASS A, OŠŤÁDAL B, PROCHÁZKA J, PELOUCH V, ŠAMÁNEK M, STEJSKALOVÁ M: Intermittent high altitude-induced changes in energy metabolism in the rat myocardium and their reversibility. Physiol Bohemoslov 38: 155-161, 1989.

BAZZI MD, YOUAKIM MA, NELSESTUEN GL: Importance of phosphatidylethanolamine for association of protein kinase C and other cytoplasmic proteins with membranes. Biochemistry 31: 1125-1134, 1992.

BENEDIKTSDOTTIR VE, SKULADOTTIR GV, GUDBJARNASON S: Effects of ageing and adrenergic stimulation on alpha 1- and beta-adrenoceptors and phospholipid fatty acids in rat heart. Eur J Pharmacol 289: 419-427, 1995.

BERGER A, GERSHWIN ME, GERMAN JB: Effects of various dietary fats on cardiolipin acyl composition during ontogeny of mice. Lipids 27: 605-612, 1992.

BITMAN J, WOOD DL: Changes in milk fat phospholipids during lactation. J Dairy Sci 73: 1208-1216, 1990.

BITMAN J, WOOD L, HAMOSH M, HAMOSH P, MEHTA NR: Comparison of the lipid composition of breast milk from mothers of term and preterm infants. Am J Clin Nutr 38: 300-312, 1983.

BOUROUDIAN M, NALBONE G, GRYNBERG A, LEONARDI J, LAFONT H: In vitro study of docosahexaenoic acid incorporation into phosphatidylcholine by enzymes of rat heart. Mol Cell Biochem 93: 119-128, 1990.

BRENNER RR: The desaturation step in the animal biosynthesis of polyunsaturated fatty acids. Lipids 6: 567-575, 1971.

BURDGE GC, DELANGE E, DUBOIS L, DUNN RL, HANSON MA, JACKSON AA, CALDER PC: Effect of reduced maternal protein intake in pregnancy in the rat on the fatty acid composition of brain, liver, plasma, heart and lung phospholipids of the offspring after weaning. Br J Nutr 90: 345-352, 2003.

CAO SG, CHENG P, ANGEL A, HATCH GM: Thyroxine stimulates phosphatidylglycerolphosphate synthase activity in rat heart mitochondria. Biochim Biophys Acta 1256: 241-244, 1995.

CHARNOCK JS, ABEYWARDENA MY, MCMURCHIE EJ, RUSSELL GR: The composition of cardiac phospholipids in rats fed different lipid supplements. Lipids 19: 206-213, 1984.

CHATTERJEE S, KOLMAKOVA A, MILLER M: The role of the phospholipid sphingomyelin in heart disease. Curr Opin Investig Drugs 7: 219-228, 2006.

CHEN X, GROSS RW: Phospholipid subclass-specific alterations in the kinetics of ion transport across biologic membranes. Biochemistry 33: 13769-13774, 1994.

CHEN ZY, CUNNANE SC: Early postnatal development in the rat is characterized by accumulation of highly unsaturated triacylglycerols. Pediatr Res 31: 47-51, 1992.

CHENG H, MANCUSO DJ, JIANG X, GUAN S, YANG J, YANG K, SUN G, GROSS RW, HAN X: Shotgun lipidomics reveals the temporally dependent, highly diversified cardiolipin profile in the mammalian brain: temporally coordinated postnatal diversification of cardiolipin molecular species with neuronal remodeling. Biochemistry 47: 5869-5880, 2008.

CLUBB FJ, BISHOP SP: Formation of binucleated myocardial cells in the neonatal rat. An index for growth hypertrophy. Lab Invest 50: 571-577, 1984.

CUNNANE SC, CHEN ZY: Quantitative changes in long-chain fatty acids during fetal and early postnatal development in rats. Am J Physiol 262: R14-R19, 1992a.

CUNNANE SC, CHEN ZY: Triacylglycerol: an important pool of essential fatty acids during early postnatal development in rats. Am J Physiol 262: R8-R13, 1992b.

ČERNOHORSKÝ J, KOLÁŘ F, PELOUCH V, KORECKÝ B, VETTER R: Thyroid control of sarcolemmal $\mathrm{Na}^{+} / \mathrm{Ca}^{2+}$ exchanger and SR $\mathrm{Ca}^{2+}$-ATPase in developing rat heart. Am J Physiol 275: H264-H273, 1998.

DAMBRIN G, BONNET D, SWYNGHEDAUW B: Biology of cardiac overload. A review. J Heart Valve Dis 3: 627633, 1994.

DE WINDT LJ, RENEMAN RS, VAN DER VUSSE GJ, VAN BILSEN M: Phospholipase A2-mediated hydrolysis of cardiac phospholipids: the use of molecular and transgenic techniques. Mol Cell Biochem 180: 65-73, 1998.

DECROCK F, GROSCOLAS R, SPEAKE BK: FA composition of heart and skeletal muscle during embryonic development of the king penguin. Lipids 37: 407-415, 2002.

DIECKMAN LJ, SOLARO RJ: Effect of thyroid status on thin-filament $\mathrm{Ca}^{2+}$ regulation and expression of troponin I in perinatal and adult rat hearts. Circ Res 67: 344-351, 1990. 
DIMITROW PP, JAWIEN M: Pleiotropic, cardioprotective effects of omega-3 polyunsaturated fatty acids. Mini Rev Med Chem 9: 1030-1039, 2009.

DORN GW, FORCE T: Protein kinase cascades in the regulation of cardiac hypertrophy. J Clin Invest 115: 527-537, 2005.

DUROT I, ATHIAS P, OUDOT F, GRYNBERG A: Influence of phospholipid long chain polyunsaturated fatty acid composition on neonatal rat cardiomyocyte function in physiological conditions and during glucose-free hypoxia-reoxygenation. Mol Cell Biochem 175: 253-262, 1997.

EMOTO K, UMEDA M: An essential role for a membrane lipid in cytokinesis. Regulation of contractile ring disassembly by redistribution of phosphatidylethanolamine. J Cell Biol 149: 1215-1224, 2000.

ESCOBAR AL, RIBEIRO-COSTA R, VILLALBA-GALEA C, ZOGHBI ME, PEREZ CG, MEJIA-ALVAREZ R: Developmental changes of intracellular $\mathrm{Ca}^{2+}$ transients in beating rat hearts. Am J Physiol 286: H971-H978, 2004.

FAAS FH, CARTER WJ: Fatty acid desaturation and microsomal lipid fatty acid composition in experimental hypothyroidism. Biochem J 207: 29-35, 1982.

FORD DA, GROSS RW: Activation of myocardial protein kinase C by plasmalogenic diglycerides. Am J Physiol 258: C30-C36, 1990.

FORD DA, HALE CC: Plasmalogen and anionic phospholipid dependence of the cardiac sarcolemmal sodium-calcium exchanger. FEBS Lett 394: 99-102, 1996.

GHEBREMESKEL K, BITSANIS D, KOUKKOU E, LOWY C, POSTON L, CRAWFORD MA: Post-natal modulation of heart and liver phosphoglyceride fatty acids in pups. Ann Nutr Metab 43: 365-373, 1999.

GHOSAL J, WHITWORTH T, CONIGLIO JG: Biosynthesis of fatty acids from $\left[1-{ }^{14} \mathrm{C}\right]$ acetate in the perfused rat heart. Biochim Biophys Acta 187: 576-578, 1969.

GIBSON RA, KNEEBONE GM: Fatty acid composition of human colostrum and mature breast milk. Am J Clin Nutr 34: 252-257, 1981.

GIRARD J, FERRE P, PEGORIER JP, DUEE PH: Adaptations of glucose and fatty acid metabolism during perinatal period and suckling-weaning transition. Physiol Rev 72: 507-562, 1992.

GLASER PE, GROSS RW: Plasmenylethanolamine facilitates rapid membrane fusion: a stopped-flow kinetic investigation correlating the propensity of a major plasma membrane constituent to adopt an HII phase with its ability to promote membrane fusion. Biochemistry 33: 5805-5812, 1994.

GONI FM, ALONSO A: Structure and functional properties of diacylglycerols in membranes. Prog Lipid Res 38: 1-48, 1999.

GROSS RW: High plasmalogen and arachidonic acid content of canine myocardial sarcolemma: a fast atom bombardment mass spectroscopic and gas chromatography-mass spectroscopic characterization. Biochemistry 23: 158-165, 1984.

GUDBJARNASON S: Prostaglandins and polyunsaturated fatty acids in heart muscle. J Mol Cell Cardiol 7: 443-449, 1975.

GUDBJARNASON S: Dynamics of n-3 and n-6 fatty acids in phospholipids of heart muscle. $J$ Intern Med Suppl 731: 117-128, 1989.

GUDBJARNASON S, BENEDIKTSDOTTIR VE: Regulation of beta-adrenoceptor properties and the lipid milieu in heart muscle membranes during stress. Mol Cell Biochem 163-164: 137-143, 1996.

GUDBJARNASON S, DOELL B, OSKARDOTTIER G, HALLGRIMSSON J: Modification of cardiac phospholipids and catecholamine stress tolerance. In: Tocoferol, Oxygen and Biomembranes. C DEDUVE, O HAYAISHI (eds), Amsterdam: Elsevier, 1978, pp 297-310.

GUDMUNDSDOTTIR A, GUDBJARNASON S: Neonatal changes in fatty acid profile of phospholipids in rat heart muscle. Biochim Biophys Acta 752: 284-290, 1983.

GUESNET P, ALASNIER C, ALESSANDRI JM, DURAND G: Modifying the $\mathrm{n}-3$ fatty acid content of the maternal diet to determine the requirements of the fetal and suckling rat. Lipids 32: 527-534, 1997.

HACK MH, HELMY FM: On the plasmalogenation of myocardial choline glycerophospholipid during maturation of various vertebrates. Comp Biochem Physiol B 89: 111-118, 1988. 
HAMPLOVÁ B, NOVÁKOVÁ O, TVRZICKÁ E, PELOUCH V, NOVÁK F: Effect of hypo- and hyperthyroid states on phospholipid composition in developing rat heart. Mol Cell Biochem 252: 295-303, 2003.

HAMPLOVÁ B, NOVÁKOVÁ O, TVRZICKÁ E, KOLÁŘ F, NOVÁK F: Protein kinase C activity and isoform expression during early postnatal development of rat myocardium. Cell Biochem Biophys 43: 105-117, 2005.

HAN XL, GROSS RW: Plasmenylcholine and phosphatidylcholine membrane bilayers possess distinct conformational motifs. Biochemistry 29: 4992-4996, 1990.

HAUFF KD, HATCH GM: Cardiolipin metabolism and Barth Syndrome. Prog Lipid Res 45: 91-101, 2006.

HERON MI, KOLÁŘ F, PAPOUŠEK F, RAKUSAN K: Early and late effect of neonatal hypo- and hyperthyroidism on coronary capillary geometry and long-term heart function in rat. Cardiovasc Res 33: 230-240, 1997.

HEYEN JR, BLASI ER, NIKULA K, ROCHA R, DAUST HA, FRIERDICH G, VAN VLEET JF, DE CIECHI P, MCMAHON EG, RUDOLPH AE: Structural, functional, and molecular characterization of the SHHF model of heart failure. Am J Physiol 283: H1775-H1784, 2002.

HLAVÁČKOVÁ M, NECKÁŘ J, JEŽKOVÁ J, BALKOVÁ P, STAŇKOVÁ B, NOVÁKOVÁ O, KOLÁŘ F, NOVÁK F: Dietary polyunsaturated fatty acids alter myocardial protein kinase $\mathrm{C}$ expression and affect cardioprotection induced by chronic hypoxia. Exp Biol Med (Maywood) 232: 823-832, 2007.

HOCH FL: Thyroid control over biomembranes. VII. Heart muscle mitochondria from L-triiodothyronine-injected rats. J Mol Cell Cardiol 14: 81-90, 1982.

HOCH FL: Lipids and thyroid hormones. Prog Lipid Res 27: 199-270, 1988.

HOCH FL: Cardiolipins and biomembrane function. Biochim Biophys Acta 1113: 71-133, 1992.

HUANG YS, WAINWRIGHT PE, REDDEN PR, MILLS DE, BULMAN-FLEMING B, HORROBIN DF: Effect of maternal dietary fats with variable n-3/n-6 ratios on tissue fatty acid composition in suckling mice. Lipids $\mathbf{2 7}$ : 104-110, 1992.

HULBERT AJ, RANA T, COUTURE P: The acyl composition of mammalian phospholipids: an allometric analysis. Comp Biochem Physiol B Biochem Mol Biol 132: 515-527, 2002.

JEŽKOVÁ J, NOVÁKOVÁ O, KOLÁŘ F, TVRZICKÁ E, NECKÁŘ J, NOVÁK F: Chronic hypoxia alters fatty acid composition of phospholipids in right and left ventricular myocardium. Mol Cell Biochem 232: 49-56, 2002.

JARKOVSKÁ D, KOLÁŘ F, PROCHÁZKA J, OŠŤÁDAL B: Structural maturation of the newborn rat myocardium: The influence of thyroid hormones. Funct Develop Morphol 4: 167-168, 1994.

KAWAGUCHI H, SHOKI M, IIZUKA K, SANO H, SAKATA Y, YASUDA H: Phospholipid metabolism and prostacyclin synthesis in hypoxic myocytes. Biochim Biophys Acta 1094: 161-167, 1991.

KENNEDY EP, WEISS SB: The function of cytidine coenzymes in the biosynthesis of phospholipides. $J$ Biol Chem 222: 193-214, 1956.

KOLÁŘ F, OŠTÁDAL B: Molecular mechanisms of cardiac protection by adaptation to chronic hypoxia. Physiol Res 53 (Suppl 1): S3-S13, 2004.

KOLÁŘ F, SEPPET EK, VETTER R, PROCHÁZKA J, GRÜNERMEL J, ZILMER K, OŠTÁDAL B: Thyroid control of contractile function and calcium handling in neonatal rat heart. Pflügers Arch 421: 26-31, 1992.

KOLÁŘ F, PAPOUŠEK F, PELOUCH V, OŠTÁDAL B, RAKUSAN K: Pressure overload induced in newborn rats: effects on left ventricular growth, morphology, and function. Pediatr Res 43: 521-526, 1998.

KOLÁŘ F, JEŽKOVÁ J, BALKOVÁ P, BŘEH J, NECKÁŘ J, NOVÁK F, NOVÁKOVÁ O, TOMÁŠOVÁ H, SRBOVÁ M, OŠTÁDAL B, WILHELM J, HERGET J: Role of oxidative stress in PKC-delta upregulation and cardioprotection induced by chronic intermittent hypoxia. Am J Physiol 292: H224-H230, 2007.

KUMAR R, CHAUDHURI BN: Altered maternal thyroid function: fetal and neonatal heart cholesterol and phospholipids. Indian J Physiol Pharmacol 37: 176-182, 1993.

LAMERS JM, DEKKERS DH, BEZSTAROSTI K, MEIJ JT, VAN HEUGTEN HA: Occurrence and functions of the phosphatidylinositol cycle in the myocardium. Mol Cell Biochem 116: 59-67, 1992.

LANDS WE: Metabolism of glycerolipides; a comparison of lecithin and triglyceride synthesis. $J$ Biol Chem 231: 883$888,1958$.

LEE HJ, MAYETTE J, RAPOPORT SI, BAZINET RP: Selective remodeling of cardiolipin fatty acids in the aged rat heart. Lipids Health Dis 5: 2, 2006. 
LI F, WANG X, CAPASSO JM, GERDES AM: Rapid transition of cardiac myocytes from hyperplasia to hypertrophy during postnatal development. J Mol Cell Cardiol 28: 1737-1746, 1996.

LI G, CHEN S, THOMPSON MN, GREENBERG ML: New insights into the regulation of cardiolipin biosynthesis in yeast: implications for Barth syndrome. Biochim Biophys Acta 1771: 432-441, 2007.

LIMAS CJ: Increased phospholipid methylation in the myocardium of hyperthyroid rats. Biochim Biophys Acta 632: 254-259, 1980.

LOKUTA AJ, COOPER C, GAA ST, WANG HE, ROGERS TB: Angiotensin II stimulates the release of phospholipidderived second messengers through multiple receptor subtypes in heart cells. J Biol Chem 269: 4832-4838, 1994.

LOPEZ JIMENEZ JA, BORDONI A, HRELIA S, ROSSI CA, TURCHETTO E, ZAMORA NS, BIAGI PL: Evidence for a detectable delta-6-desaturase activity in rat heart microsomes: aging influence on enzyme activity. Biochem Biophys Res Commun 192: 1037-1041, 1993.

MCCALLISTER LP, PAGE E: Effects of thyroxin on ultrastructure of rat myocardial cells: a stereological study. J Ultrastruct Res 42: 136-155, 1973.

MOALIC JM, CHARLEMAGNE D, MANSIER P, CHEVALIER B, SWYNGHEDAUW B: Cardiac hypertrophy and failure - a disease of adaptation. Modifications in membrane proteins provide a molecular basis for arrhythmogenicity. Circulation 87 (Suppl IV): IV21-IV26, 1993.

MRNKA L, NOVÁKOVÁ O, PELOUCH V, NOVÁK F: Phospholipid composition in the rat heart exposed to pressure overload from birth. Physiol Res 45: 83-85, 1996.

NAKAMURA S, KIYOHARA Y, JINNAI H, HITOMI T, OGINO C, YOSHIDA K, NISHIZUKA Y: Mammalian phospholipase D: phosphatidylethanolamine as an essential component. Proc Natl Acad Sci USA 93: 43004304, 1996.

NALBONE G, GRYNBERG A, CHEVALIER A, LEONARDI J, TERMINE E, LAFONT H: Phospholipase A activity of cultured rat ventricular myocyte is affected by the nature of cellular polyunsaturated fatty acids. Lipids $\mathbf{2 5}$ : 301-306, 1990.

NISHIZUKA Y: Intracellular signaling by hydrolysis of phospholipids and activation of protein kinase C. Science 258: 607-614, 1992.

NOVÁK F, TVRZICKÁ E, PELOUCH V, JEŽKOVÁ J, SMIK D, NOVÁKOVÁ O: Phospholipid composition of immature rat myocardium exposed to chronic hypoxia and the effect of normoxic recovery. Collect Czech Chem Commun 69: 674-688, 2004.

NOVÁK F, TVRZICKÁ E, HAMPLOVÁ B, KOLÁŘ F, NOVÁKOVÁ O: Postnatal development of phospholipids and their fatty acid profile in rat heart. Mol Cell Biochem 293: 23-33, 2006.

NOVÁKOVÁ O, DRNKOVÁ J, KUBIŠTA V, NOVÁK F: Regulation of phospholipid degradation and biosynthesis in the heart by isoprenaline: effect of mepacrine. Physiol Res 43: 151-156, 1994.

NOVÁKOVÁ O, PELOUCH V, MRNKA L, TVRZICKÁ E, NOVÁK F: Phospholipid composition in mitochondria of pressure overloaded maturating rat heart. J Mol Cell Cardiol 34: A87, 2002.

NOVOTNÝ J, BOUŘOVÁ L, MÁLKOVÁ O, SVOBODA P, KOLÁŘ F: G proteins, beta-adrenoreceptors and betaadrenergic responsiveness in immature and adult rat ventricular myocardium: influence of neonatal hypo- and hyperthyroidism. J Mol Cell Cardiol 31: 761-772, 1999.

OKA T, ITOI T, TERADA N, NAKANISHI H, TAGUCHI R, HAMAOKA K.: Change in the membranous lipid composition accelerates lipid peroxidation in young rat hearts subjected to 2 weeks of hypoxia followed by hyperoxia. Circ J 72: 1359-1366, 2008.

OLIVETTI G, ANVERSA P, LOUD AV: Morphometric study of early postnatal development in the left and right ventricular myocardium of the rat. II. Tissue composition, capillary growth, and sarcoplasmic alterations. Circ Res 46: 503-512, 1980.

OŠTÁDAL B, KOLÁŘ F: Cardiac adaptation to chronic high-altitude hypoxia: beneficial and adverse effects. Respir Physiol Neurobiol 158: 224-236, 2007.

OŠTÁDAL B, KOLÁŘ F, PELOUCH V, WIDIMSKÝ J: Ontogenetic differences in cardiopulmonary adaptation to chronic hypoxia. Physiol Res 44: 45-51, 1995. 
OŠTÁDAL B, OŠŤÁDALOVÁ I, DHALLA NS: Development of cardiac sensitivity to oxygen deficiency: comparative and ontogenetic aspects. Physiol Rev 79: 635-659, 1999.

PAGE E: Quantitative ultrastructural analysis in cardiac membrane physiology. Am J Physiol 235: C147-C158, 1978.

PAGE E, EARLEY J, POWER B: Normal growth of ultrastructures in rat left ventricular myocardial cells. Circ Res 35 (Suppl II): 12-16, 1974.

PAGE E, MCCALLISTER LP: Quantitative electron microscopic description of heart muscle cells. Application to normal, hypertrophied and thyroxin-stimulated hearts. Am J Cardiol 31: 172-181, 1973.

PARADIES G, RUGGIERO FM, PETROSILLO G, QUAGLIARIELLO E: Age-dependent decline in the cytochrome c oxidase activity in rat heart mitochondria: role of cardiolipin. FEBS Lett 406: 136-138, 1997.

PEHOWICH DJ: Hypothyroid state and membrane fatty acid composition influence cardiac mitochondrial pyruvate oxidation. Biochim Biophys Acta 1235: 231-238, 1995.

PELOUCH V, DIXON IM, GOLFMAN L, BEAMISH RE, DHALLA NS: Role of extracellular matrix proteins in heart function. Mol Cell Biochem 129: 101-120, 1993.

PIC P, BOUQUIN JP: Thyrotropic hormone and thyroidal function initiation in fetal rat. $J$ Dev Physiol 7: 207-214, 1985.

POST JA, VERKLEIJ AJ, ROELOFSEN B, OP DE KAMP JA: Plasmalogen content and distribution in the sarcolemma of cultured neonatal rat myocytes. FEBS Lett 240: 78-82, 1988.

REIBEL DK, O'ROURKE B, FOSTER KA, HUTCHINSON H, UBOH CE, KENT RL: Altered phospholipid metabolism in pressure-overload hypertrophied hearts. Am J Physiol 250: H1-H6, 1986.

RITTER O, NEYSES L: The molecular basis of myocardial hypertrophy and heart failure. Trends Mol Med 9: 313-321, 2003.

RUSTOW B, SCHLAME M, RABE H, REICHMANN G, KUNZE D: Species pattern of phosphatidic acid, diacylglycerol, CDP-diacylglycerol and phosphatidylglycerol synthesized de novo in rat liver mitochondria. Biochim Biophys Acta 1002: 261-263, 1989.

SCHLAME M, REN M: Barth syndrome, a human disorder of cardiolipin metabolism. FEBS Lett 580: 5450-5455, 2006.

SCHLAME M, REN M, XU Y, GREENBERG ML, HALLER I: Molecular symmetry in mitochondrial cardiolipins. Chem Phys Lipids 138: 38-49, 2005.

SEDMERA D, THOMPSON RP, KOLÁR̆ F: Effect of increased pressure loading on heart growth in neonatal rats. J Mol Cell Cardiol 35: 301-309, 2003.

SHAIKH SR, CHEREZOV V, CAFFREY M, STILLWELL W, WASSALL SR: Interaction of cholesterol with a docosahexaenoic acid-containing phosphatidylethanolamine: trigger for microdomain/raft formation? Biochemistry 42: 12028-12037, 2003.

SIMONIDES WS, VAN HARDEVELD C: Effects of hypothyroidism on the distribution and fatty acyl composition of phospholipids in sarcoplasmic reticulum of fast skeletal muscle of the rat. Biochim Biophys Acta 924: 204-209, 1987.

ŠKÁRKA L, BARDOVÁ K, BRAUNER P, FLACHS P, JARKOVSKÁ D, KOPECKÝ J, OŠŤÁDAL B: Expression of mitochondrial uncoupling protein 3 and adenine nucleotide translocase 1 genes in developing rat heart: putative involvement in control of mitochondrial membrane potential. J Mol Cell Cardiol 35: 321-330, 2003.

SLATER SJ, KELLY MB, YEAGER MD, LARKIN J, HO C, STUBBS CD: Polyunsaturation in cell membranes and lipid bilayers and its effects on membrane proteins. Lipids 31 (Suppl): S189-S192, 1996.

SMITH HE, PAGE E: Ultrastructural changes in rabbit heart mitochondria during the perinatal period. Neonatal transition to aerobic metabolism. Dev Biol 57: 109-117, 1977.

SMOLICH JJ: Ultrastructural and functional features of the developing mammalian heart: a brief overview. Reprod Fertil Dev 7: 451-461, 1995.

SPARAGNA GC, CHICCO AJ, MURPHY RC, BRISTOW MR, JOHNSON CA, REES ML, MAXEY ML, MCCUNE SA, MOORE RL: Loss of cardiac tetralinoleoyl cardiolipin in human and experimental heart failure. $J$ Lipid Res 48: 1559-1570, 2007. 
STUHNE-SEKALEC L, WASSENAAR M, JACKOWSKI G, STANACEV NZ: Comparison of the biosynthesis and composition of polyglycerophosphatides and phosphatidylinositols in mitochondria and microsomes isolated from neonatal and adult rat heart and liver. Membr Biochem 9: 29-45, 1990.

SUAREZ A, FAUS MJ, GIL A: Dietary long-chain polyunsaturated fatty acids modify heart, kidney, and lung fatty acid composition in weanling rats. Lipids 31: 345-348, 1996.

SZYMANSKA G, PIKULA S, ZBOROWSKI J: Effect of hyper- and hypothyroidism on phospholipid fatty acid composition and phospholipases activity in sarcolemma of rabbit cardiac muscle. Biochim Biophys Acta 1083: 265-270, 1991.

TAPPIA PS: Phospholipid-mediated signaling systems as novel targets for treatment of heart disease. Can J Physiol Pharmacol 85: 25-41, 2007.

TAPPIA PS, NIJJAR MS, MAHAY A, AROUTIOUNOVA N, DHALLA NS: Phospholipid profile of developing heart of rats exposed to low-protein diet in pregnancy. Am J Physiol 289: R1400-R1406, 2005.

TAYLOR WA, XU FY, MA BJ, MUTTER TC, DOLINSKY VW, HATCH GM: Expression of monolysocardiolipin acyltransferase activity is regulated in concert with the level of cardiolipin and cardiolipin biosynthesis in the mammalian heart. BMC Biochem 3: 9, 2002.

TSALOUHIDOU S, ARGYROU C, THEOFILIDIS G, KARAOGLANIDIS D, ORFANIDOU E, NIKOLAIDIS MG, PETRIDOU A, MOUGIOS V: Mitochondrial phospholipids of rat skeletal muscle are less polyunsaturated than whole tissue phospholipids: implications for protection against oxidative stress. J Anim Sci 84: 2818$2825,2006$.

VAN DEN HOFF MJ, VAN DEN EIJNDE SM, VIRAGH S, MOORMAN AF: Programmed cell death in the developing heart. Cardiovasc Res 45: 603-620, 2000.

VAN DER VUSSE GJ, GLATZ JF, STAM HC, RENEMAN RS: Fatty acid homeostasis in the normoxic and ischemic heart. Physiol Rev 72: 881-940, 1992.

VASDEV SC, KORECKY B, RASTOGI RB, SINGHAL RL, KAKO KJ: Myocardial lipid metabolism in cardiac hyper- and hypo-function. Studies on triiodothyronine-treated and transplanted rat hearts. Can J Physiol Pharmacol 55: 1311-1319, 1977.

VIGOUROUX E: Dynamic study of post-natal thyroid function in the rat. Acta Endocrinol (Copenh) 83: 752-762, 1976.

WASSALL SR, BRZUSTOWICZ MR, SHAIKH SR, CHEREZOV V, CAFFREY M, STILLWELL W: Order from disorder, corralling cholesterol with chaotic lipids. The role of polyunsaturated lipids in membrane raft formation. Chem Phys Lipids 132: 79-88, 2004.

WHITSETT JA, POLLINGER J, MATZ S: beta-Adrenergic receptors and catecholamine sensitive adenylate cyclase in developing rat ventricular myocardium: effect of thyroid status. Pediatr Res 16: 463-469, 1982.

WIBO M, KOLÁŘ F, ZHENG L, GODFRAIND T: Influence of thyroid status on postnatal maturation of calcium channels, beta-adrenoceptors and cation transport ATPases in rat ventricular tissue. J Mol Cell Cardiol 27: 1731-1743, 1995.

WOOD R, HARLOW RD: Structural analyses of rat liver phosphoglycerides. Arch Biochem Biophys 135: 272-281, 1969.

XU Y, KELLEY RI, BLANCK TJ, SCHLAME M: Remodeling of cardiolipin by phospholipid transacylation. $J$ Biol Chem 278: 51380-51385, 2003.

YAMAOKA-KOSEKI S, URADE R, KITO M: Cardiolipins from rats fed different dietary lipids affect bovine heart cytochrome c oxidase activity. J Nutr 121: 956-958, 1991.

YAMASHITA A, SUGIURA T, WAKU K: Acyltransferases and transacylases involved in fatty acid remodeling of phospholipids and metabolism of bioactive lipids in mammalian cells. J Biochem 122: 1-16, 1997.

YOSHIKAWA T, FURUKAWA Y, WAKAMATSU Y, TAKEMURA S, TANAKA H, KONDO M: Experimental hypoxia and lipid peroxide in rats. Biochem Med 27: 207-213, 1982.

ZACHOWSKI A: Phospholipids in animal eukaryotic membranes: transverse asymmetry and movement. Biochem $J$ 294: 1-14, 1993.

ZAROR-BEHRENS G, KAKO KJ: Positional and fatty acid specificity of monoacyl- and diacylglycerol 3-phosphate formation by rabbit heart microsomes. Biochim Biophys Acta 441: 1-13, 1976. 
ZEISEL SH, CHAR D, SHEARD NF: Choline, phosphatidylcholine and sphingomyelin in human and bovine milk and infant formulas. $J$ Nutr 116: 50-58, 1986.

ZHENG L, WIBO M, KOLÁř F, GODFRAIND T: Calcium channels and cation transport ATPases in cardiac hypertrophy induced by aortic constriction in newborn rats. Mol Cell Biochem 163-164: 23-29, 1996. 